\title{
Do VCs use inside rounds to dilute founders? Some evidence from Silicon Valley
}

\section{Citation}

Brian J. Broughman \& Jesse M. Fried, Do VCs Use Inside Rounds to Dilute Founders? Some Evidence from Silicon Valley, 18 J. Corp. Fin. 1104 (2012).

\section{Published Version}

10.1016/j.jcorpfin.2012.06.012

\section{Permanent link}

http://nrs.harvard.edu/urn-3:HUL.InstRepos:30011621

\section{Terms of Use}

This article was downloaded from Harvard University's DASH repository, and is made available under the terms and conditions applicable to Open Access Policy Articles, as set forth at http:// nrs.harvard.edu/urn-3:HUL.InstRepos:dash.current.terms-of-use\#OAP

\section{Share Your Story}

The Harvard community has made this article openly available.

Please share how this access benefits you. Submit a story.

\section{Accessibility}


ISSN 1936-5349 (print)

ISSN 1936-5357 (online)

\title{
HARVARD
}

JOHN M. OLIN CENTER FOR LAW, ECONOMICS, AND BUSINESS

\author{
DO VCs USE INSIDE ROUNDS \\ TO DILUTE FOUNDERS? \\ SOME EVIDENCE FROM \\ SILICON VALLEY
}

Brian J. Broughman \& Jesse M. Fried

Discussion Paper No. 716

$07 / 2012$

Harvard Law School

Cambridge, MA 02138

This paper can be downloaded without charge from:

The Harvard John M. Olin Discussion Paper Series:

http://www.law.harvard.edu/programs/olin_center/

This paper is also a discussion paper of the

John M. Olin Center’s Program on Corporate Governance. 


\title{
Do VCs Use Inside Rounds to Dilute Founders? Some Evidence from Silicon Valley
}

\author{
Brian J. Broughman ${ }^{\mathrm{a}}$, Jesse M. Fried ${ }^{\mathrm{b} *}$
}

July 1, 2012

Forthcoming, Journal of Corporate Finance

\begin{abstract}
In the bank-borrower setting, a firm's existing lender may exploit its positional advantage to extract rents from the firm in subsequent financings. Analogously, a startup’s existing venture capital investors (VCs) may dilute the founder through a follow-on financing from these same VCs (an "inside” round) at an artificially low valuation. Using a hand-collected dataset of Silicon Valley startup firms, we find little evidence that VCs use inside rounds to dilute founders. Instead, our findings suggest that inside rounds are generally used as "backstop financing” for startups that cannot attract new money, and these rounds are conducted at relatively high valuations (perhaps to reduce litigation risk).
\end{abstract}

Keywords: Venture capital, dilution, corporate governance, inside rounds, opportunism, corporate law, inside financing, adverse selection

a Indiana University Maurer School of Law

${ }^{b}$ Harvard Law School

* Corresponding author: Harvard Law School, Cambridge, MA 02138, Tel: 617-384-8158, e-mail: jfried@law.harvard.edu (J.Fried). 


\section{Do VCs Use Inside Rounds to Dilute Founders? Some Evidence from Silicon Valley}

(C) 2012. All Rights Reserved. Brian J. Broughman \& Jesse M. Fried

\section{Introduction}

Venture capitalists (VCs) play a critical role in the financing of startup firms (Gompers \& Lerner, 1999; Hellmann \& Puri, 2000). VCs typically invest through several rounds of equity financing. Each round is separately negotiated and priced. After the initial VC investment, “follow-on” rounds of financing could be provided by either (a) the firm's existing VC investors exclusively (an inside round) or (b) a group that includes and is usually led by a VC that did not invest in the startup’s earlier rounds (an outside round).

Historically, most follow-on financings were structured as outside rounds (Lerner, 1994). Bringing new investors into a startup can yield a number of benefits. Among other things, a new investor pricing the deal can mitigate conflict between the entrepreneur and existing VCs over the value of the firm (Admati \& Pfleiderer, 1994) and expand the startup’s contact network (Hochberg, Ljungqvist, \& Lu, 2007).

However, in recent years, more than half of follow-on rounds have been structured as inside rounds (Bengtsson \& Sensoy, 2009). In this paper, we posit and seek to test two potential explanations for the use of inside rounds: (1) “dilution” - inside rounds are used to extract rents from the entrepreneur; and (2) "backstop financing" - inside rounds are used to prop up startups that cannot attract new VCs offering financing on reasonable terms. 
Turning first to dilution, inside rounds could be used to extract rents from entrepreneurs through either informational lock-in or coercive self-dealing. Informational lock-in occurs when information asymmetry between a firm's existing investors and potential outside investors makes it difficult for the firm to obtain competitive financing from an outside investor (Sharpe 1990; Rajan 1992; von Thadden 1994), thus enabling the existing investors to extract rents in subsequent financings. Although informational lockin is typically associated with a bank-borrower relationship, it may also enable VC financers to use inside rounds to extract rents from the entrepreneur. As in the bankborrower setting, each VC-backed firm typically receives more than one round of financing, and a firm's existing VCs may have proprietary information about the firm that could affect the firm's ability to get follow-on financing from a new investor.

Coercive self-dealing is a more aggressive form of rent extraction than informational lock-in. It involves VCs using their extensive control rights in the startup (Kaplan \& Stromberg, 2003; Hellmann, 1998) to force the startup to sell them cheap stock through an inside round (Fluck, Garrison, \& Myers, 2005). In fact, while litigation by entrepreneurs against VCs is rare, many of the lawsuits that are filed allege that VCs used an inside round to dilute the firm's founders (Atanasov, et. al., 2008). ${ }^{1}$

\footnotetext{
${ }^{1}$ In one well-publicized case (Kalashian v. Advent, 1997) a firm’s VCs, while in control of the board and holding over $90 \%$ of the firm's stock, conducted an inside financing round at $\$ 0.005$ per share, reducing the founders' proportional ownership from $8 \%$ to $0.007 \%$. Several years later, the VCs took the firm through an IPO and the share price reached $\$ 70$. The founders sued, and after a weeklong trial the VCs settled the case for \$15M (King, 1997). After the settlement came to light, corporate lawyers advised VCs to reduce litigation risk by finding outside investors to price follow-on rounds, and use inside rounds only as a last resort (King, 1997).
} 
An alternative explanation to dilution (either via informational lock-in or coercive self-dealing) is that existing VCs may use inside rounds as a form of backstop financing: when current VCs are unable to induce outside investors to invest in the firm on acceptable terms (or at all) current VCs may be forced to resort to inside financing to keep the firm going. Backstop financing is consistent with evidence that VCs are patient investors (Puri and Zarutskie, forthcoming) and may well explain why the increase in inside rounds over the last half decade coincided with declines in startup valuations after the dot-com bubble. Unfortunately, little is known about whether VCs tend to use inside financing rounds to dilute founders or for other purposes, such as backstopping.

This paper uses detailed data from a sample of VC-backed startups to examine the purpose and effect of inside rounds. Standard VC databases, such as VentureXpert (VX), do not provide information on round terms or economic returns, and thus cannot easily be used to test alternative explanations for inside financing. Instead, we use a hand-collected data-set of 50 Silicon Valley firms sold in M\&A transactions in 2003 or 2004. The dataset was assembled primarily for a study of the conflicts between VCs and entrepreneurs around M\&A exits (see Broughman and Fried, 2010). However, it includes enough finegrained information about the firms' financings to compare the terms and financial returns of inside and outside rounds. Moreover, it appears to be the only available dataset with such detailed information about VC investments. ${ }^{2}$

\footnotetext{
${ }^{2}$ Da Rin, Hellmann, and Puri (2011) discuss available data sources for empirical research into VC financing (see section 2), emphasizing the lack of reliable round-level data on financial returns (see section 5). See also Metrick and Yasuda (2011).
} 
We find little evidence of the use of inside rounds for dilutive financing in our sample. Instead, we find that inside rounds are generally (but not always) used for backstop financing - to support marginal firms that cannot attract outside investors. Our analysis also indicates that when VCs conduct inside rounds, they tend to use relatively high valuations, perhaps to reduce litigation risk.

Our analysis proceeds in two steps. First, we examine the incidence of inside rounds. Consistent with backstop financing, we find that inside rounds are more likely to occur in firms where VCs lose money. Firms whose exits generated profits for the VCs rarely used inside financing. We also find that inside rounds increase when market conditions (as proxied by NASDAQ and startup valuations) deteriorate. Entrepreneurs' own accounts of their firms' fundraising efforts also point to inside rounds generally not being used for dilution but rather for backstop financing. According to almost every founder in our sample, existing VCs actively sought outside financing, and resorted to inside rounds only when outside financing was not available.

Even if VCs do not prefer inside rounds, and conduct inside rounds only when outside rounds are not feasible, they may still use inside rounds to dilute founders by setting valuations too low. Thus, the second step of our analysis is to compare the valuations used in inside rounds to those used in outside rounds. For each firm, we determine the relative valuation of the last financing round by dividing the valuation used in the last financing round by the best available proxy of what the firm was actually worth at the time: its eventual sale price. If VCs use inside rounds to dilute founders, we would expect the relative valuations of inside rounds to be lower than the relative valuations of outside rounds. In fact, the relative valuations of inside rounds are higher than outside 
rounds; in various regression models the difference is both economically and statistically significant. We perform various robustness checks on these results and reach the same results: inside rounds are overvalued relative to (and yield lower returns than) outside rounds. We also find some evidence consistent with valuations being driven by litigation considerations.

We also asked founders about their perceptions of the fairness of each financing round. Consistent with Admati and Pfleiderer (1994), none of the outside rounds was perceived as unfair. On the other hand, three of 21 founders who experienced inside rounds indicated that they believed the terms of the inside rounds in their firms were unfair; one of them sued (on a variety of grounds, including dilution via an inside round). Interestingly, however, in each of these three firms the VCs lost money and would have been entitled to receive all of the sale proceeds via their liquidation preferences, regardless of the valuations used in pre-sale financing rounds. Thus, while the founders might have been diluted ex ante at the time of financing, they were not diluted ex post.

Given that our sample is limited in number, as well as by time (2003 - 2004), place (Silicon Valley), and type of exit (acquisition), we consider the generalizability of our results to other settings. Using VX, we create a second, random sample of US-based VCbacked firms that had a variety of exit outcomes and operated over a broad time range. Although VX does not provide data on economic returns, it does provide data on the identity of the VCs investing in each round and on firm outcomes (IPO, acquisition, defunct, still active). We find that the incidence of inside rounds in the VX sample is consistent with the financing patterns observed in our sample: inside rounds tend to be preceded by deteriorating market conditions and declining firm values and followed by 
worse firm outcomes. Our analysis suggests that even if inside rounds are sometimes used for dilution, this does not appear to be a widespread practice either in our sample or in the broader population.

Our paper contributes to a better understanding of governance within private VCbacked startups before they are sold. While academics have studied the contracts VCs use when investing in startups (Kaplan and Stromberg, 2003) and how these arrangements evolve (Bengtsson and Sensoy, 2009) and affect the allocation of sale proceeds (Broughman and Fried, 2010), little is known about how VCs actually exercise control within these firms prior to exit. Our study provides preliminary evidence suggesting that VCs generally do not use their positional advantage to dilute founders via inside rounds. Rather, our study suggests that inside rounds are generally used when outside financing is unavailable, and VCs do not underprice (and may well overprice) inside rounds.

Our paper also contributes to the literature on valuations used in VC-backed firms. Earlier studies have focused on a variety of factors affecting valuation in this setting, including capital flows into VC funds (Gompers and Lerner, 2000); VC quality (Hsu, 2004); VC bargaining power (Heughebaert and Manigart, 2010); and fund size (Cumming and Dai, 2011). Our study suggests that assigned valuations may well be systematically higher when follow-on financing is structured as an inside round.

Finally, our project relates to the more general literature on inside financing. While economists have developed this theory in the context of lending relationships (Sharpe 1990; Rajan 1992; von Thadden 1994), and found evidence of informational lock-in within inside bank financing (e.g., Ioannidou and Ongena, 2010), this effect could also arise in the context of VC financing. Our study provides preliminary evidence suggesting that 
informational lock-in may not arise in the VC setting, perhaps because VCs fear being sued for breach of fiduciary duty. Our findings thus imply that informational lock-in may not be an inherent feature of inside financing, but rather may depend on specific features of the institutional setting.

The remainder of the paper is organized as follows. Part 2 explains why VCs may have an incentive to use inside financing rounds to dilute founders. Part 3 describes our dataset. Part 4 presents our findings on the incidence of inside financing. Part 5 compares the valuations and returns of inside rounds and outside rounds. Part 6 discusses the generalizability of our results. Part 7 concludes.

\section{Why Inside Rounds?}

Startup firms typically receive financing from VCs through several rounds (or stages) of investment, each separately negotiated and priced. The identity of participating investors and the terms of financing may differ from one round to the next (Gompers, 1995). Each round of financing is typically syndicated among several different VC funds (Gompers and Lerner, 1999). ${ }^{3}$ One of these funds - typically the fund with the largest share of the round - is designated the "lead investor" and negotiates the terms of investment with the startup's board and its shareholders. The terms of investment include cash flow rights and control rights, such as protective provisions (e.g. the right to veto certain transactions) and board seats.

\footnotetext{
${ }^{3}$ The literature describes several benefits of syndication (Lerner, 1994; Brander, et. al., 2002; Sorenson and Stuart, 2001).
} 
One of the most important financial terms is the valuation assigned to the startup. VCs typically invest in startups through some form of preferred stock that is convertible into common shares. For a given amount invested, a lower valuation implies a larger postconversion percentage ownership of the firm for the VCs. Thus, everything else equal, VCs investing in the firm will prefer a lower valuation, and the founder a higher valuation.

In the first round of financing, the lead VC investor negotiates a valuation with the startup's founders, who initially control the firm. The initial valuation of the startup emerges out of this arm's-length bargaining process. In a follow-on round of financing, there are VCs on each side of the bargaining table. And in an inside round, the same VCs sit on both sides of the table.

Historically, most follow-on financings were structured as outside rounds (Lerner, 1994), where a new VC negotiates the terms and typically makes the largest investment, and some or all of the existing VCs invest alongside the new VC. Economists have identified a number of potential benefits to bringing new investors into the startup. New investors can mitigate conflicts between the founder and existing VCs over the value of the firm by bargaining over terms at arm’s-length (Admati \& Pfleiderer, 1994; Lerner, 1994; Brander, et. al., 2002), thereby reducing litigation risk (King, 1997). New investors can also expand the startup’s contact network (Hochberg, Ljungqvist, and Lu, 2007) and improve fund diversification (Tian, 2008).

From the entrepreneur's perspective, there is minimal risk of dilution in an outside round. Although many (or all) of the existing VCs typically co-invest in outside rounds (Admati and Pfleiderer, 1994), the need to preserve equity-based incentives for employees and the presence of a large outside investor in the round tend to make the existing VCs as a 
group net (indirect) sellers rather than net buyers. Consequently, in an outside round, the existing VC investors (like the founder in the initial financing) typically have an incentive to push for a high valuation to minimize the dilutive effect of the round on their preexisting interests in the firm.

In recent years, however, more than half of follow-on rounds have been structured as inside rounds - rounds where there are no new investors (Bengtsson and Sensoy, 2009). As in an outside round, not all of the existing investors necessarily participate. Some VCs may invest more than their proportionate share and others may invest less, depending on their assessments of the firm, their access to capital, and other considerations. The distinguishing feature of an inside round is that all the investors in the round already own shares in the firm. Below, we discuss two explanations for inside rounds: (1) that they are used to dilute the entrepreneur and (2) that they provide "backstop” financing for firms that cannot attract outside financing. ${ }^{4}$

\subsection{Inside Rounds for Dilution}

Inside rounds could be used to dilute founders through two different mechanisms: (1) information lock-in and (2) coercive self-dealing.

Informational Lock-in. In the bank-financing context, theory predicts that a firm’s existing bank can extract rents in follow-on loans because information asymmetry and

\footnotetext{
${ }^{4}$ There may be other reasons for inside rounds. For example, an inside round may be used when the transaction costs associated with identifying, recruiting, and integrating a new investor exceed the potential benefits of bringing in a new investor.
} 
adverse selection effects make it difficult for the firm to obtain competitive financing from a new lender (Sharpe 1990; Rajan 1992; von Thadden 1994). There is indeed evidence consistent with such “informational lock-in.” (Ioannidou and Ongena, 2010).

Similarly, existing VCs may be able to use proprietary (or 'soft') information gained through their relationship with a startup to extract above-market returns through a subsequent round of inside financing. The existing VCs do not need to actively block the startup from receiving outside financing; rather, adverse selection makes outside financing unattractive to the entrepreneur even relative to a dilutive inside round. ${ }^{5}$

Coercive Self-Dealing. More aggressively, VCs may be able to use their control rights to forcibly dilute the entrepreneur. VCs typically have substantial influence over, and often acquire outright control of, their portfolio firms (Kaplan \& Stromberg, 2003). As commentators have recognized, such power creates the potential for self-dealing in inside rounds (Atanasov, et. al., 2008; Broughman, 2010; Padilla, 2001; Bartlett and Garlitz, 1995), a risk that increases with the degree of control exerted by the VCs.

If the VCs control the board and own a sufficient amount of the equity, they can essentially dictate the terms of financing of an inside round (subject to the possibility of a fiduciary-duty lawsuit). ${ }^{6}$ Even if VCs lack board control, they may be able to use

\footnotetext{
${ }^{5}$ To reduce adverse selection, outside VCs typically ask that existing VCs participate in the new round (Admati and Pfleiderer, 1994). But existing VCs could simply refuse to invest alongside an outside VC, forcing the VC to worry about adverse selection and offer worse terms to the startup.

${ }^{6}$ If the firm is domiciled in California, common shareholders as a class must approve the financing. Thus, VCs cannot force through a financing unless the VCs have negotiated drag-along rights that compel common shareholders to support transactions approved by the VCs, the VCs convert some of their preferred stock to
} 
alternative sources of control to coerce a firm in need of capital to accept dilutive financing. For example, VCs typically negotiate rights to block any subsequent financing round they oppose. They can thus block any financing round other than their own, starving the firm of capital and forcing it to accept an undervalued inside round that gives the VCs a larger equity share of the company at the entrepreneur's expense.

\subsection{Inside Rounds as Backstop Financing}

An alternative to the dilution explanation is that inside rounds are used to support firms that cannot find an outside investor willing to invest on what are perceived as reasonable terms (or at all). If an outside investor cannot be found, the existing VCs generally have two options: either conduct an inside round or liquidate the startup through a dissolution or sale. Dissolution is likely to substantially reduce- or totally wipe outthe value of the VCs' existing investments in the firm. It will also force the VCs to mark down the value of their investments, potentially making it more difficult to raise their next fund. Similarly, selling the firm takes time, and is less likely to yield a high price if the firm is seen as running out of funds and desperate for a savior. For a firm that cannot attract outside financing, an inside round can provide useful "backstop financing."

Even if an inside round is used as backstop financing, the VCs are likely to have at least some influence over the round's valuation. An inside round could thus involve both backstop financing and dilution. For example, a firm's existing VCs prefer to bring in an

common stock, or the VCs can induce a majority of the common shareholders to support the transaction. See Broughman and Fried (2010); Fried and Ganor (2006). 
outside investor on fair terms, but cannot find such an investor. They thus resort to an inside round, but then use their control over the firm to dilute the entrepreneur. To the extent there is such a round, we would not consider the round to be "backstop financing" but rather as involving “dilution.” For our purposes, an inside round is driven by backstop financing only if the VCs do not use a low valuation in the round.

\subsection{Predictions}

The dilution and backstop-financing explanations for inside rounds generate different predictions about the incidence and valuation of inside rounds. Whether dilution occurs via informational lock-in or coercive self-dealing, inside rounds will have lower valuations (relative to a firm's actual value) than outside rounds. ${ }^{7}$ If, on the other hand, VCs generally used inside rounds for backstop financing, we would not expect the valuations of inside rounds to be lower than that of outside rounds. Indeed, the valuations used in inside rounds might be higher. Because an inside round increases litigation risk (King, 1997), VCs forced (or choosing) to conduct an inside round may decide to offer a higher valuation than would otherwise be used.

\footnotetext{
${ }^{7}$ Depending on the allocation of control rights and the amount of information asymmetry in a particular firm, the informational lock-in and coercive self-dealing mechanisms may yield different predictions about the likelihood of dilutive financing. Nonetheless, both mechanisms predict that inside rounds will tend to be underpriced and generate higher returns than outside rounds. We can thus reject both versions of the dilution hypothesis if we find that inside rounds perform no better (or even worse) than outside rounds.
} 


\section{Data}

To explore the purpose and effect of inside rounds, we use data from a sample of Silicon Valley startup firms. The remainder of this section (i) describes the data source, (ii) describes the firms in the dataset, and (iii) summarizes the terms used in these firms' follow-on financings.

\subsection{Data Source}

Standard VC databases, such as VentureXpert (VX), do not provide the type of detail necessary to explore whether inside rounds are used for dilution or other purposes. Such databases do not always disclose critical round terms (including liquidation preferences and even valuation (Kaplan, Sensoy, \& Strömberg, 2002)). More importantly, they do not report the payoff round investors receive when they exit the startup.

We thus use a hand-collected data-set of 50 Silicon Valley firms sold in M\&A transactions in 2003 or 2004 . The dataset was assembled primarily for a study of the conflicts between VCs and entrepreneurs around M\&A exits (see Broughman and Fried, 2010), but includes enough fine-grained information about the firms’ financings to compare the terms and performance of inside and outside rounds in the sample. In particular, for each financing round we observe (i) the composition of the investor group (ii) the allocation of board seats and shareholder voting rights, (iii) detailed cash-flow rights (including valuation, participation rights, conversion rights, liquidation preferences, and cumulative dividends), and (iv) the economic payout upon exit (including IRR). The data collection process is described in Broughman and Fried (2010). 
For the current study on inside rounds, we removed 5 of the 50 firms because they did not receive follow-on financing, or because the database was missing information on the valuation or other terms of a follow-on round. We thus have an effective sample of 45 firms, with 90 follow-on rounds of financing.

\subsection{Sample Description}

Our sample firms are "high-tech" businesses, primarily in the biotech, software, telecommunications, and internet sectors (Panel A of Table 1). The concentration of firms in the sample is representative of VC-financed firms generally (Kaplan and Strömberg, 2003 at 284). Consistent with Daines (2002) and Bebchuk and Cohen (2003), all of the sample firms were incorporated in either their home state (which, for all of these firms, was California) or Delaware. Panel B shows that 31 sample firms were incorporated in Delaware and 14 in California.

At the time of sale, the sample firms had received an average of \$44 million in VC funding, ${ }^{8}$ and had been operating for an average of approximately five years. The average sale price was \$55 million, but there was considerable variance in exit outcomes. Some firms were essentially liquidated, yielding a sale price less than one million dollars, while other firms were sold for considerably more than $\$ 100$ million.

We report data on how the sale proceeds were divided among the different classes of shareholders. Since we know the date of each round and the date of sale, we can

\footnotetext{
${ }^{8}$ The companies in our sample also received, on average, \$0.15 million in entrepreneur/family financing, and $\$ 0.45$ million in angel financing before VCs invested.
} 
calculate the VCs' internal rate of return (IRR) for each round and for each firm. The VCs’ average IRR was 0.20 . However, only 16 of the 45 firms were sold for a profit, indicating that the average IRR is skewed by a few highly profitable firms. Panel B provides descriptive statistics on the amount invested, years of operation, entrepreneur experience, and sale price.

\section{[INSERT TABLE 1 HERE]}

\section{3. $\quad$ Financing Round Characteristics}

The 45 firms in this study received, on average, three rounds of VC financing

(Panel B, Table 1). Of the 90 follow-on rounds, 26 (29\%) were inside, and 64 (71\%) were outside. We collect detailed information on each round, including the composition of the investor group, the allocation of board control, the VCs' cash-flow rights, and the valuation used in the financing. ${ }^{9}$ Table 2 defines variables used throughout the remainder of the paper and provides a correlation matrix.

\section{[INSERT TABLE 2 HERE]}

We record the nominal post-money valuation for each round of financing. ${ }^{10}$ The nominal valuation is equal to the VCs' investment divided by the fraction of common

\footnotetext{
${ }^{9}$ While we were able to get data on which VC led each round, and the identities of all the VCs participating in the round, we were unable to get the precise amount invested by each VC in each round.

${ }^{10}$ While nominal valuation is the standard method of valuing VC-backed startups, it implicitly assumes that the common stock held by entrepreneurs has the same value as the VCs' preferred stock. In fact, preferred stock typically includes a liquidation preference and other rights that make it more valuable than common stock (Metrick 2007). To account for the value of these rights we also record valuation on an implied basis using an option valuation technique outlined in Metrick (2007). For purposes of calculating implied valuations, we use an annualized volatility for the VC industry of $89 \%$ (Cochrane, 2005). For details on this
} 
stock that the VCs are entitled to on a fully converted basis. If the nominal pre-money valuation (post-money valuation less the amount invested) is higher than the post-money valuation of the previous round, the new round is considered an "up round.” If the nominal pre-money valuation is lower than the post-money valuation of the previous round, it is considered a "down round." If the pre-money valuation of the new round is the same as the previous round's post-money valuation, the round is called “even.” Of the 90 rounds, 45 (50\%) were up, 14 (16\%) were even, and 31 (34\%) were down.

\section{Incidence of Inside Rounds}

We begin by examining the incidence of inside rounds: the relationship between inside rounds and down rounds, the relationship between inside rounds and firm profitability (whether the firms generate profits or losses for the VCs), and entrepreneurs' own accounts of why their firms had inside rounds. All of this evidence is generally consistent with inside rounds being used as backstop financing to support marginal firms that cannot otherwise obtain financing, and generally inconsistent with the dilution explanation for inside rounds.

\subsection{Inside Rounds and Down Rounds}

approach, see Metrick (2007, pp. 252-87). The method of valuation - nominal or implied - does not affect our findings reported below. We ran all regressions in Table 4 (below) using both methods of valuation, and found qualitatively similar results. 
Figure 1 shows the relationship between the identity of the lead investor and round valuation changes. Inside-led rounds are generally down (or even) rounds, while outside rounds are typically up rounds.

\section{[INSERT FIGURE 1 HERE]}

The correlation between inside and down rounds is potentially consistent with both dilution and backstop financing. If inside rounds were used to support marginal firms, we would expect firms whose values have declined to be more likely to receive inside rounds (backstop). But the observed correlation is also consistent with existing VCs opportunistically exploiting information lock-in or their control rights to underprice inside rounds (dilution). Under the backstop financing explanation, lower valuations lead to more inside rounds. Under the dilution explanation, inside rounds lead to lower valuations.

In our sample, declines in real valuation appear to drive the use of inside rounds, and not vice versa. Figure 2 shows graphically that inside rounds are highly correlated with changes in NASDAQ, a proxy for startup market conditions. Both down and inside rounds decline in tandem as NASDAQ increases from 1997 to 2000, and then inside and down rounds increase in tandem as NASDAQ drops from 2000 to $2004 .^{11}$

\section{[INSERT FIGURE 2 HERE]}

\footnotetext{
${ }^{11}$ In unreported regressions, we find that, controlling for various firm characteristics, a decline in NASDAQ between financing rounds increase the likelihood that the subsequent round is (1) a down or flat round; (2) an inside round; or (3) a down (or flat) inside round. Thus, consistent with backstop financing, deteriorating market conditions increase the use of inside rounds in our sample.
} 


\subsection{Inside Rounds and Firm IRR}

Further evidence that inside rounds are used for backstop financing (and not dilution) can be found in the relationship between the use of inside financing and the IRR generated by each firm for its VCs (“Firm IRR”). Figure 3 shows a strong negative relationship between the fraction of financing coming from inside rounds and Firm IRR. This suggests that inside rounds are more likely to occur in firms that perform worst.

\section{[INSERT FIGURE 3 HERE]}

In each sample firm, VCs invest through preferred stock with a liquidation preference of at least $1 \mathrm{x}$ the amount invested. Thus, if the firm is sold for a loss (Firm IRR $<0$ ), the entrepreneur is not entitled to any of the exit proceeds, and cannot have been diluted ex post by any financing round. For inside financing to shift value from a firm's entrepreneurs to its VCs ex post, the firm must be sold for a profit (Firm IRR $>0$ ).

Table 3 provides additional information on the relationship between inside financing and Firm IRR. Twenty-one firms received at least one round of inside financing. Only four of these firms (19\%) were sold for a profit. Of the 24 firms that did not receive inside financing, 12 were sold for a profit (50\%). In addition, Firm IRR is lower for firms that received inside rounds $(-0.33)$ than for firms that received only outside rounds $(0.65)$. These differences are statistically significant at the $5 \%$ and $10 \%$ levels respectively.

Table 3 also shows that most "profit” firms (Firm IRR > 0) did not receive any inside financing at all. In fact, only $25 \%$ of profit firms received any inside financing. On average, profit firms received only $5 \%$ of their total financing from inside rounds. In contrast, 59\% of “loss” firms (Firm IRR < 0) received inside financing, and on average 
received $20 \%$ of their total financing from inside rounds. These differences are statistically significant at the $5 \%$ and $1 \%$ levels, respectively.

\section{[INSERT TABLE 3]}

\subsection{Founders' Own Assessments}

We asked the founders to describe the circumstances of each round of financing. Almost all of the founders indicated that the existing VCs had encouraged them to find outside VCs to invest in the firm. With two exceptions described below, inside rounds were only conducted when outside financing was not available.

We will call the two exceptions "Firm X" and "Firm Y" (the names are omitted to preserve confidentiality). In Firm X, both the original investor (a private equity shop that typically invests in larger businesses and does not describe itself as a VC firm) and the founder saw no reason to conduct outside rounds. When Firm X was eventually sold, it generated considerable profits for both the investor and the founder.

In Firm Y, the VCs pushed through a bridge financing round with large repayment obligations shortly before the firm was sold; other investors (including the firm's common shareholders) were excluded from participating in this bridge financing. Because of the circumstances surrounding this financing round and other alleged misbehavior by the VCs, the founder sued the VCs. The case was eventually settled for an undisclosed amount. While a total of three firms in our sample experienced litigation, Firm $\mathrm{Y}$ was the only firm in our sample that saw litigation over an allegedly dilutive round of financing. 


\section{Analysis of Inside vs. Outside Round Valuations}

The data presented in Part 4 suggests that most (but not all) inside rounds are undertaken to provide financing to firms that have difficulty attracting outside investors, generally the most poorly-performing firms. However, even if inside rounds were not caused by a desire to dilute founders but rather by the failure to find outside investors, inside rounds could still dilute founders if the assigned valuations were too low. We now consider the valuations used in inside rounds, focusing primarily on the valuations used in the last financing round of each firm.

\subsection{Last-Round Valuations: Inside vs. Outside}

To determine whether inside rounds are dilutive, we would ideally measure the difference between the valuation used in each follow-on financing round and the firm's true value at the time of the financing, and thereby be able to determine whether inside rounds are systematically underpriced. Unfortunately, however, it is impossible to observe the "true" value of a private company before it is sold. Thus, we use the eventual sale price of the firm - negotiated at arm's length between the buyer and the firm's investors - as a proxy for the firm's "true" valuation in the last round of financing. This strategy permits us to compare inside and outside valuations in the last round of financing of each firm.

To be sure, the sale price reflects in part events that occur after the last round of financing. Consequently, sale price is not a perfect indicator of the firm's actual value at the last round of financing. Nonetheless, as long as such distortions are randomly 
distributed or otherwise controlled for in the regressions below, the sale price can serve as an unbiased estimate of a firm's value at the time of the last financing. ${ }^{12}$

Thus, for each firm, we compare the valuation of the firm used in the last round of VC financing (last round valuation) to the sale price. Our dependent variable is the ratio (Last Round Valuation)/(Sale Price) or “LRV/SP”. If inside rounds are used to dilute founders, LRV/SP will be systematically lower in Inside rounds than in Outside rounds. If VCs are constrained by reputational considerations or fear of litigation (Black and Gilson, 1998), LRV/SP will be the same in Inside rounds as in Outside Rounds, or even higher.

Figure 4 illustrates the distribution of LRV/SP for inside rounds and outside rounds. Inside rounds often have an LRV/SP ratio exceeding 2. In contrast, in outside rounds LRV/SP is generally close to 1 . Inside rounds appear overvalued relative to the ultimate sale price, while outside rounds do not.

\section{[INSERT FIGURE 4 HERE]}

To test for dilution in a multivariate setting, we estimate the following equation:

$$
\log (L R V / S P)=F(\text { Inside, } \text { Controls })
$$

The dependent variable in Eq. (1) is the natural log of LRV/SP. We take the natural log so that data are not left-truncated at zero.

\footnotetext{
${ }^{12}$ The presence of a new outside investor may add value to a firm by bringing new capabilities and connections (Brander, et. al., 2002). This, in turn, might appear to create an endogeneity problem: if firms that attract outside investors unexpectedly turn out to be more valuable for this reason, their relative lastround valuations (last-round valuation divided by sale price) will be biased downward. But this endogeneity problem would arise only if the parties could not, at the time of the last round of financing, form an unbiased estimate of the outside investor's effect on the firm's value and incorporate this estimate into the round valuation.
} 
Our primary treatment variable records whether the last round of financing was an Inside round. Because the risk of dilutive financing is greater when VCs control the board, we include VC Control as right-hand side variable. If dilutive financing is common, Inside will have a negative effect on $\log (\operatorname{LRV} / S P)$, especially if the VCs also control the board.

We include other factors that might affect the sale price and the last round valuation. California equals one if the firm was incorporated in California, and zero otherwise. Relative to Delaware incorporation, California domicile is likely to provide greater protection to minority shareholders (Broughman and Fried, 2010). Consequently, California domicile may limit a VC's ability or willingness to push for a low valuation.

$\triangle N A S D A Q$ Sale (\%) equals the percentage change in NASDAQ from the date of financing to the date of sale. This term controls for factors that might affect the sale price but could not have been foreseen by the parties on the date of financing. VC Reputation equals one if the VC firm leading the round of financing was formed prior to the median year of formation for the VCs in our sample (1990), and zero otherwise. This term controls for possible valuation discounts given to VCs with good reputations (Hsu, 2004). Duration Fin. to Sale equals the number of years between the last round of financing and the sale of the firm. Finally, Investment measures the amount invested in the last round of financing (in millions).

Regression results are shown in Table 4. Model (4-1) reports univariate results, and in models (4-2) and (4-3) we add the above control variables and industry dummies. In each specification, we find a significant positive correlation between Inside and the LRV/SP ratio. Relative to the sale price, significantly higher valuations are used in inside 
last rounds than in outside last rounds. These results are inconsistent with the use of inside rounds for dilutive financing.

[INSERT TABLE 4 HERE]

\subsection{Robustness Checks}

We conduct several robustness checks on the results reported in Table 4. First, we address the possibility that outliers may drive our results. Given a small sample size, outlier observations could have a large effect on the coefficient estimates reported in Table 4. We thus re-estimate model (4-2) using weighted least squares ('WLS') and robust regression ('RREG'). The WLS estimates reported in model (4-4) are weighted based on the amount invested in the round, ensuring that our results are not driven by small investments of little economic significance. RREG assigns weights to each observation in order to reduce the effect of outliers and then re-estimates on the weighted observations. RREG estimates are reported in model (4-5). We find the same basic result using WLS and RREG: inside financing is associated with a positive and significant effect on the relative valuation of the firm. Our results thus do not appear to be driven by outliers.

Second, we separately focus on a subset of the last-round valuations - profit firms (Firm IRR $>0$ ). Inside financing might serve different purposes in profit firms than in loss firms. In loss firms, inside financing may serve a backstop-financing function. In profit firms, inside financing could be used for dilution. If so, inside rounds may be undervalued in profit firms but not in loss firms. To address this possibility we re-estimate model (4-2) limited to the subsample of profit firms. Results are reported in model (4-6). Even among 
the 16 profit firms, inside rounds are associated with higher relative valuations. In both the full sample and the profit-firm subsample, inside rounds seem to be overvalued relative to outside rounds.

Our results could be biased by omitted variables that correlate with both the use of inside financing and valuation. Ideally, we would instrument for the use of inside financing. However, a suitable instrument does not appear available. ${ }^{13}$ Thus, although we attempt to address this concern by examining valuation relative to the firm's ultimate sale price (LRV/SP), and by controlling for other factors that may affect round pricing, we cannot claim to have established causation firmly.

\subsection{Returns from All Follow-On Rounds: Inside vs. Outside}

We also examine the returns of all 90 follow-on rounds (not just the last 45 rounds). If inside rounds were consistently underpriced, they should yield higher returns than outside rounds. Figure 5 shows the VCs' internal rate of return for each round of financing (Round IRR) for all 90 follow-on rounds based on the time of financing. On average, inside rounds have a lower IRR over almost the entire time period. To be sure, the results reported in Figure 5 do not control for other factors affecting round

\footnotetext{
${ }^{13}$ In an earlier draft, we had considered "VC fund age" as a possible instrument for the availability of inside financing. Limited partnership agreements typically place restrictions on additional investments as a fund ages, making it difficult for an older fund (or a syndicate of older funds) to finance a startup through an inside round. Unfortunately, fund age is a weak instrument with a very low first-stage F-statistic (Staiger \& Stock, 1997). Also, VCs' practice of cross-fund investing complicates the use of fund age as an instrumental variable.
} 
performance. But they do provide additional evidence that inside rounds are not underpriced, and, if anything, are likely to be overpriced.

\section{[INSERT FIGURE 5 HERE]}

\subsection{Founders' Own Assessments}

Finally, we asked founders if any of their follow-on financing terms were "unfair." Consistent with Admati \& Pfeiderer's (1994) claim that outside rounds are used to mitigate conflicts between the existing VCs and the founder over valuation, none of the founders claimed that any outside rounds were "unfair." However, three respondents (including the founder of Firm Y) claimed that an inside round was dilutive. Interestingly, in each of these three firms, the VCs suffered losses (Firm IRR $<0$ ). Even if the firms received artificially low valuations, these low valuations did not expropriate value from entrepreneurs ex post, since the VCs would have been entitled to the full merger payout (via liquidation preferences) regardless of the valuation assigned in an earlier financing round. In other words, the founders may have been diluted ex ante, but they were not diluted ex post.

Founders' own accounts suggest that inside rounds, whatever their cause, are generally not unfairly priced. While founders' perceptions could be distorted, they are consistent with the results of our econometric analysis. Taken together, the founders' accounts and our statistical analysis suggest that most inside rounds do not dilute founders, at least in our sample of Silicon Valley portfolio firms. 


\subsection{Why Might Inside Rounds be Overvalued?}

In our sample, there is some evidence that inside rounds are overvalued relative to outside rounds. We describe several possible explanations for why inside rounds might be relatively overvalued. Although we do not seek to test these explanations formally, we do note where the explanations appear consistent with our data and econometric results.

Litigation Risk. A board conducting a follow-on financing faces a higher risk of liability if the round includes a controlling shareholder - a shareholder who has de facto control of the board and can thus (essentially) dictate the corporation's actions. Being sued imposes many costs, including a potential hit to reputation (Atanasov, et. al., 2008). This risk is heightened if there is no outside investor to price the deal. Because VCs are often controlling shareholders and participate in follow-on rounds of financing, they are counseled to seek an outside investor to price the deal and only conduct inside rounds as a last resort (King, 1997). The risk of liability may also be higher if the firm is domiciled in California (rather than Delaware), as California law is generally more protective of minority shareholders (Broughman and Fried, 2010).

To the extent that litigation concerns affect valuations, we would thus expect valuations to be higher when (i) VCs control the board, (ii) the firm is domiciled in California (rather than Delaware), or (iii) the financing is an inside round. Consistent with this prediction, VC Control, California, and Inside have positive coefficients in all models reported in Table 4. These results suggest that VCs are constrained by litigation concerns when pricing follow-on rounds of financing.

Non-Litigation Reasons for Overvaluing Inside Rounds. First, existing VCs may deliberately overvalue the firm to engage in "false signaling." In particular, overvaluing an 
inside round can be used to “window-dress” VCs’ returns to facilitate fund-raising (Cumming and Walz, 2010; Lerner, 1994), reduce the likelihood of receiving a low-ball offer at the next round of outside financing, and mitigate the adverse effects of a low-round financing on employee morale at the firm.

Second, VCs may overvalue inside rounds to reduce “down-round” costs. If the firm's value has declined since the previous round, a round at the "correct” valuation will trigger the anti-dilution provisions in the existing VCs' investment contracts. These provisions must often be renegotiated to preserve incentives for the firm's employees (Bartlett, 2003). To avoid these costs, existing VCs may prefer to conduct an even (flat) round rather than a down-round in order to avoid triggering anti-dilution provisions. Indeed, as Figure 1 indicates, a very high proportion of inside rounds are flat rounds, and a very high proportion of flat rounds are inside rounds.

Third, existing VCs may simply overvalue the firm because of over-optimism or "hubris” (Roll, 1986). If an outside offer is received, hubris or over-optimism might cause the existing VCs to turn down the offer because they mistakenly view it as "too low," causing them to finance the firm at a valuation that the VCs view as reasonable but is in fact too high. Similarly, if an outside offer is not received, hubristic or over-optimistic VCs may conduct an inside round that is inadvertently overpriced.

\section{Are the Results Generalizable?}


The sample is limited to 45 Silicon Valley firms sold in 2003 or 2004 for which entrepreneurs agreed to provide us information, raising questions about the generalizability of our results.

To begin, the entrepreneurs who agreed to provide us with data may not be representative of the sample population. It is possible that non-responding entrepreneurs were more likely to have experienced dilution from inside rounds. We thus compare the frequency of litigation involving the VC investors in the sample firms to other Silicon Valley firms sold in M\&A transactions in 2003 and 2004. We find a higher incidence of litigation in our sample. ${ }^{14}$ Thus, conflict between the entrepreneurs and VC investors does not appear to be underrepresented in our sample. ${ }^{15}$

Three other representativeness issues are worth noting. First, our sample does not include exits taking the form of a straight dissolution or IPO. VCs might use inside rounds to dilute entrepreneurs only in their best-performing firms - those that are most likely to exit via IPO. By omitting IPO exits, our results may understate the extent to which VCs use inside rounds for dilution. Second, California VCs and startups appear to use financing contracts that are more favorable to entrepreneurs (Bengtsson and Ravid, 2010), raising the possibility that non-California VCs investing outside of California may be more

\footnotetext{
${ }^{14}$ Among the 45 sample firms, there were three lawsuits filed by founders against VC investors (one alleging dilutive inside financing and other forms of misbehavior, and the other two alleging only other forms of VC misbehavior), a litigation rate of approximately $6 \%$. Among the 148 out-of-sample firms, there was only one founder who filed a lawsuit against VC investors, a litigation rate of less than $1 \%$.

${ }^{15}$ To further control for non-random sampling, we re-estimate model 4-2 using a Heckman two-stage regression model. We use VX to provide partial data for the out-of-sample firms in the first-stage selection model. In the full Heckman model (unreported), we find a qualitatively similar result to the findings reported in table 4: inside rounds are positively correlated with LRV/SP.
} 
likely to use inside rounds for dilution than the VCs in our sample. Third, the firms in our sample received much of their financing at the height of the dot-com bubble and were sold a couple of years after it burst. The performance of inside rounds during this period may not reflect the performance of inside rounds in other periods.

To address these concerns, we use VentureXpert (VX) to construct a random sample of VC-backed firms located across the US, covering all exit outcomes, and operating over a broad period of time (the "VX sample"). We classify follow-on financing rounds in the VX sample as inside or outside, and then compare the incidence of inside rounds in our main sample to the VX sample.

Although VX's data are relatively limited, the financing patterns that emerge in the VX sample are broadly consistent with data from our main sample. First, the frequency of inside rounds in our main sample is similar to the frequency of inside rounds in both California-based firms and acquired firms in the VX sample. Second, as in the main sample, inside rounds in the VX sample tend to be preceded by declines in NASDAQ and are strongly associated with even- and down-rounds, not up-rounds. Third, inside rounds in the VX sample are also, on average, followed by worse firm outcomes. For example, inside rounds made up approximately $20 \%$ of the follow-on financings of firms that exited via IPO but over $40 \%$ of the follow-on financings of firms that failed or remained unsold many years after their initial financings. Given that far fewer startups exit through IPOs than fail or remain unsold, the primary selection bias regarding inside rounds in the main sample appears to be the underrepresentation of inside rounds in struggling firms, not the underrepresentation of inside rounds in IPO firms. A description and analysis of the VX sample can be found in the Appendix. This analysis suggests that even if inside rounds 
were more frequently used for dilution outside our sample than inside our sample, they are generally not used for that purpose.

\section{Conclusion}

Using a hand-collected data set of Silicon Valley VC-backed firms, we investigate whether VCs investing in these firms used inside rounds - financing rounds in which only existing VCs participate - to dilute founders via an informational lock-in effect or coercive self-dealing. We find little evidence in our sample that suggests inside rounds are used to engage in dilutive financing. Instead, we find that inside rounds are generally used for what we call "backstop financing" - financing used to support marginal firms that cannot attract outside investors. Our analysis also indicates that when VCs conduct inside rounds they tend to use relatively high valuations, perhaps to reduce litigation risk.

Our paper provides a new window into the governance of private VC-backed startups before they are sold by providing evidence that VCs generally do not use their positional advantage and control rights to dilute entrepreneurs. It also suggests that the valuations used in VC rounds are affected not only by such factors as VC quality and VC bargaining power but also by whether the round is inside or outside. Finally, it provides preliminary evidence that the informational lock-in effect observed in inside bank financing may not arise in the VC setting, perhaps because fear of fiduciary-duty litigation prevents VCs from underpricing inside rounds. We hope that our work is useful to courts, legislatures, practitioners, and academics seeking to understand and improve the corporate governance of VC-backed firms. 


\section{Acknowledgments}

For helpful conversations and comments on earlier versions of this paper, we are grateful to Robert Bartlett, Lucian Bebchuk, Sascha Becker, Ola Bengtsson, Effi Benmelech, Tom Chang, John Coates, Paul Gompers, Jim Greiner, Darian Ibrahim, Steve Kaplan, Louis Kaplow, Kate Litvak, Edwin Miller, Eric Rasmussen, Jeff Stake, an anonymous referee, and seminar participants at Harvard Law School, Indiana University, the University of San Diego, Vanderbilt, the 2008 Law and Entrepreneurship Retreat, the University of Cincinnati, the University of Wisconsin, the 2009 American Law and Economics Association annual meeting, the 2009 Law and Society Association annual meeting, the 2009 Midwest Law and Economics Association annual meeting, the 2009 Conference on Empirical Legal Studies, and the Summer 2010 NBER Entrepreneurship Working Group meeting. We would also like to thank Joy Batra, Albert Chang, June Hwang, Jake Robinson, Jennifer Su, Bruce Sun, and Fennie Wang for valuable research assistance. VentureReporter.net provided access to their database of mergers and

acquisitions. This project was generously supported by a grant from the Kauffman Foundation through the Lester Center for Entrepreneurship and Innovation at UC Berkeley. Finally, we thank the many entrepreneurs who agreed to provide data for our research.

\section{Appendix}


To supplement the results of our study of the main sample in this paper, we generate and analyze a random sample of VC-backed startups from VentureXpert (VX), the most commonly-used commercial database for empirical work related to venture capital (Da Rin, Hellmann, and Puri 2011). VX does not provide data on round returns and is often missing information on round valuation. VX does, however, let us compare the incidence of inside rounds in VX to our main sample. The results from our VX study are broadly consistent with the use of inside rounds for backstop financing rather than dilution.

\section{A. VX Sample Description}

The VX sample is composed of VC-backed firms randomly selected from all US firms in VentureXpert (VX) that were founded between 1/1/1996 and 12/31/2002, received at least $\$ 5 \mathrm{M}$, and disclosed valuation data for at least one round of financing. 4070 firms in VX met the above criteria; we selected every $40^{\text {th }}$ firm, giving us a random sub-sample of 102 firms.

Most of the VX sample firms (94 out of 102) received follow-on financing. We exclude follow-on rounds that occur within 3 months of the previous financing; even though they are reported as "rounds" in VX they are unlikely to be separately negotiated (Bengtsson \& Sensoy, 2009; Cumming \& Dai, 2010). We also exclude rounds that do not include a VC investor. We are left with a total of 312 follow-on rounds in the VX sample. We coded the round status - inside or outside - for each of the 312 follow-on rounds. There were 186 (60\%) outside rounds and 126 (40\%) inside rounds. Firms in the VX sample received an average of 3 follow-on rounds of financing.

Table A1 provides firm-level statistics for the businesses in the VX sample. The firms are primarily in the internet, medical/health, and software sectors (Panel A of Table A1). The concentration in high-tech businesses is similar to the main sample. As of June 2010, VX sample firms received on average \$50 million in VC funding, compared to \$44 million 
in the main sample. ${ }^{16}$ More than half of the VX sample firms (54\%) were located in California, giving us information on the use of inside rounds both in and outside Silicon Valley.

${ }^{16}$ VX sample firms that are still "active” may receive additional financing in the future. 
Table A1: VX Sample Firm Data (n=102)

Panel A: Industry Distribution of VX Sample Firms

\begin{tabular}{lc}
\hline Internet Specific & 33 \\
Medical/Health & 22 \\
Computer Software & 17 \\
Biotechnology & 9 \\
Communications & 9 \\
Other IT & 12 \\
\hline
\end{tabular}

Panel B:Overview

\begin{tabular}{lccc|ccc} 
& \multicolumn{3}{c|}{ VX Sample } & \multicolumn{3}{c}{ Main Sample } \\
Variable & Obs. & Count & Mean & Obs. & Count & Mean \\
\hline Total Invested (\$M) & 102 & & 50.477 & 45 & & 43.999 \\
Number of Rounds & 102 & & 4.069 & 45 & & 3.00 \\
Year of First Financing & 102 & & 1999.402 & 45 & & 1998.38 \\
California Location & 102 & 47 & .461 & 45 & 45 & 1 \\
IPO & 102 & 14 & .137 & n/a & & n/a \\
Acquisition & 102 & 40 & .392 & 45 & 45 & 1 \\
Active & 102 & 28 & .275 & n/a & & n/a \\
Defunct & 102 & 20 & .196 & n/a & & n/a \\
\hline
\end{tabular}

Table A1 (Panel B) also reports data on the current exit status - IPO, Acquisition, Active, or Defunct - for the VX sample firms. Just over half the VX sample firms had achieved an exit event by mid-2010, either an IPO (14\%) or private sale (39\%). The remaining firms are either defunct (20\%) or remain active (27\%). 
Table A2: VX Sample Follow-on Round Data $(n=312)$

\begin{tabular}{|c|c|c|c|c|c|c|c|c|c|c|}
\hline & \multicolumn{5}{|c|}{ VX Sample } & \multicolumn{5}{|c|}{ Main Sample } \\
\hline & \multirow[b]{2}{*}{$(\mathrm{n}=)$} & \multicolumn{2}{|c|}{ Inside } & \multicolumn{2}{|c|}{ Outside } & \multirow[b]{2}{*}{$(n=)$} & \multicolumn{2}{|c|}{ Inside } & \multicolumn{2}{|c|}{ Outside } \\
\hline & & $\#$ & $(\%)$ & $\#$ & $(\%)$ & & $\#$ & (\%) & $\#$ & $(\%)$ \\
\hline Full Sample & 312 & 126 & $40 \%$ & 186 & $60 \%$ & 90 & 26 & $29 \%$ & 64 & $71 \%$ \\
\hline \multicolumn{11}{|l|}{ Sorted by State } \\
\hline CA & 143 & 47 & $33 \%$ & 96 & $67 \%$ & 90 & 26 & $29 \%$ & 64 & $71 \%$ \\
\hline Non-CA & 169 & 79 & $47 \%$ & 90 & $53 \%$ & $\mathrm{n} / \mathrm{a}$ & & & & \\
\hline \multicolumn{11}{|c|}{ Sorted by Exit Status } \\
\hline IPO & 48 & 10 & $21 \%$ & 38 & $79 \%$ & $\mathrm{n} / \mathrm{a}$ & & & & \\
\hline Acquisition & 118 & 40 & $34 \%$ & 78 & $66 \%$ & 90 & 26 & $29 \%$ & 64 & $71 \%$ \\
\hline Active & 103 & 57 & $55 \%$ & 46 & $45 \%$ & $\mathrm{n} / \mathrm{a}$ & & & & \\
\hline Defunct & 43 & 19 & $44 \%$ & 24 & $56 \%$ & $\mathrm{n} / \mathrm{a}$ & & & & \\
\hline \multicolumn{11}{|c|}{ Sorted by Valuation } \\
\hline Up & 73 & 9 & $12 \%$ & 64 & $88 \%$ & 45 & 2 & $4 \%$ & 43 & $96 \%$ \\
\hline Down & 26 & 8 & $31 \%$ & 18 & $69 \%$ & 31 & 15 & $48 \%$ & 16 & $52 \%$ \\
\hline Even & 13 & 7 & $54 \%$ & 6 & $46 \%$ & 14 & 9 & $64 \%$ & 5 & $36 \%$ \\
\hline Missing & 200 & 102 & $51 \%$ & 98 & $49 \%$ & $\mathrm{n} / \mathrm{a}$ & & & & \\
\hline \multicolumn{11}{|l|}{ Sorted by Year } \\
\hline 1998 (or earlier) & 20 & 5 & $25 \%$ & 15 & $75 \%$ & 6 & 2 & $33 \%$ & 4 & $67 \%$ \\
\hline 1999 & 35 & 3 & $9 \%$ & 32 & $91 \%$ & 12 & 0 & $0 \%$ & 12 & $100 \%$ \\
\hline 2000 & 50 & 13 & $26 \%$ & 37 & $74 \%$ & 18 & 3 & $17 \%$ & 15 & $83 \%$ \\
\hline 2001 & 44 & 16 & $36 \%$ & 28 & $64 \%$ & 24 & 7 & $29 \%$ & 17 & $71 \%$ \\
\hline 2002 & 28 & 15 & $54 \%$ & 13 & $46 \%$ & 19 & 9 & $47 \%$ & 10 & $53 \%$ \\
\hline 2003 & 27 & 15 & $56 \%$ & 12 & $44 \%$ & 11 & 5 & $45 \%$ & 6 & $55 \%$ \\
\hline 2004 & 25 & 12 & $48 \%$ & 13 & $52 \%$ & $\mathrm{n} / \mathrm{a}$ & & & & \\
\hline 2005 & 22 & 13 & $59 \%$ & 9 & $41 \%$ & $\mathrm{n} / \mathrm{a}$ & & & & \\
\hline 2006 & 21 & 11 & $52 \%$ & 10 & $48 \%$ & $\mathrm{n} / \mathrm{a}$ & & & & \\
\hline 2007 & 18 & 10 & $56 \%$ & 8 & $44 \%$ & $\mathrm{n} / \mathrm{a}$ & & & & \\
\hline 2008 (or later) & 22 & 13 & $59 \%$ & 9 & $41 \%$ & $\mathrm{n} / \mathrm{a}$ & & & & \\
\hline
\end{tabular}

The VX sample includes 312 follow-on rounds, of which 126 (40\%) are inside rounds and 186 (60\%) are outside rounds. Table A2 (above) shows the frequency of inside and outside financing in the VX sample and the main sample sorted across a number of dimensions. 


\section{B. Comparison of VX Sample to Main Sample}

The remainder of this appendix compares the use of inside financing in the VX sample to the main sample.

\section{Frequency of Inside Rounds}

Overall, inside rounds are somewhat more common in the VX sample (40\%) than in the main sample (29\%). Inside rounds occur more frequently outside California (47\%) and in firms that have failed to achieve a successful exit (i.e. firms that are defunct or active). Inside rounds are less common in IPO firms (21\%) than in the main sample. Limiting the VX sample to firms located in California (33\%) or to acquired firms (34\%) yields a similar frequency of inside financing as in the main sample. This suggests that the main sample is fairly representative of California-based firms and firms that were ultimately acquired, but may understate the overall frequency of inside financing.

More than half of the inside rounds in the VX sample, however, occurred in struggling firms, namely those that are defunct (19) or active (57). Collectively defunct and active firms make up 60\% (76/126) of the inside rounds in the VX sample. Since all firms in the VX sample received initial financing in 2002 or earlier, the "active” firms are likely to be "walking dead" or "zombie” firms that are unlikely to yield large returns to the VCs. The primary selection bias regarding inside rounds in the main sample appears to be the underrepresentation of inside rounds in struggling firms, not the underrepresentation of inside rounds in IPO firms.

\section{Inside Rounds and NASDAQ}

As in the main sample, firms in the VX sample are significantly more likely to rely on inside financing when NASDAQ - a rough proxy for startups' value - has declined since the prior round. Figure A1 displays, for each year in the period 1997-2004, the frequency of inside and down round financing in both the VX sample and the main sample as well as the NASDAQ index. The top portion graphs weekly NASDAQ closing prices from1997 to 2004. The middle and bottom portion illustrate the frequency of inside and down rounds in the main sample (middle portion) and VX sample (bottom portion) over the same time 
period. In both samples, as NASDAQ rose in the late 1990s, inside rounds and down rounds decreased in frequency; when NASDAQ began falling in 2000, the frequency of inside rounds and down rounds increased.

\section{Figure A1: VX Sample Inside Financing by Year}

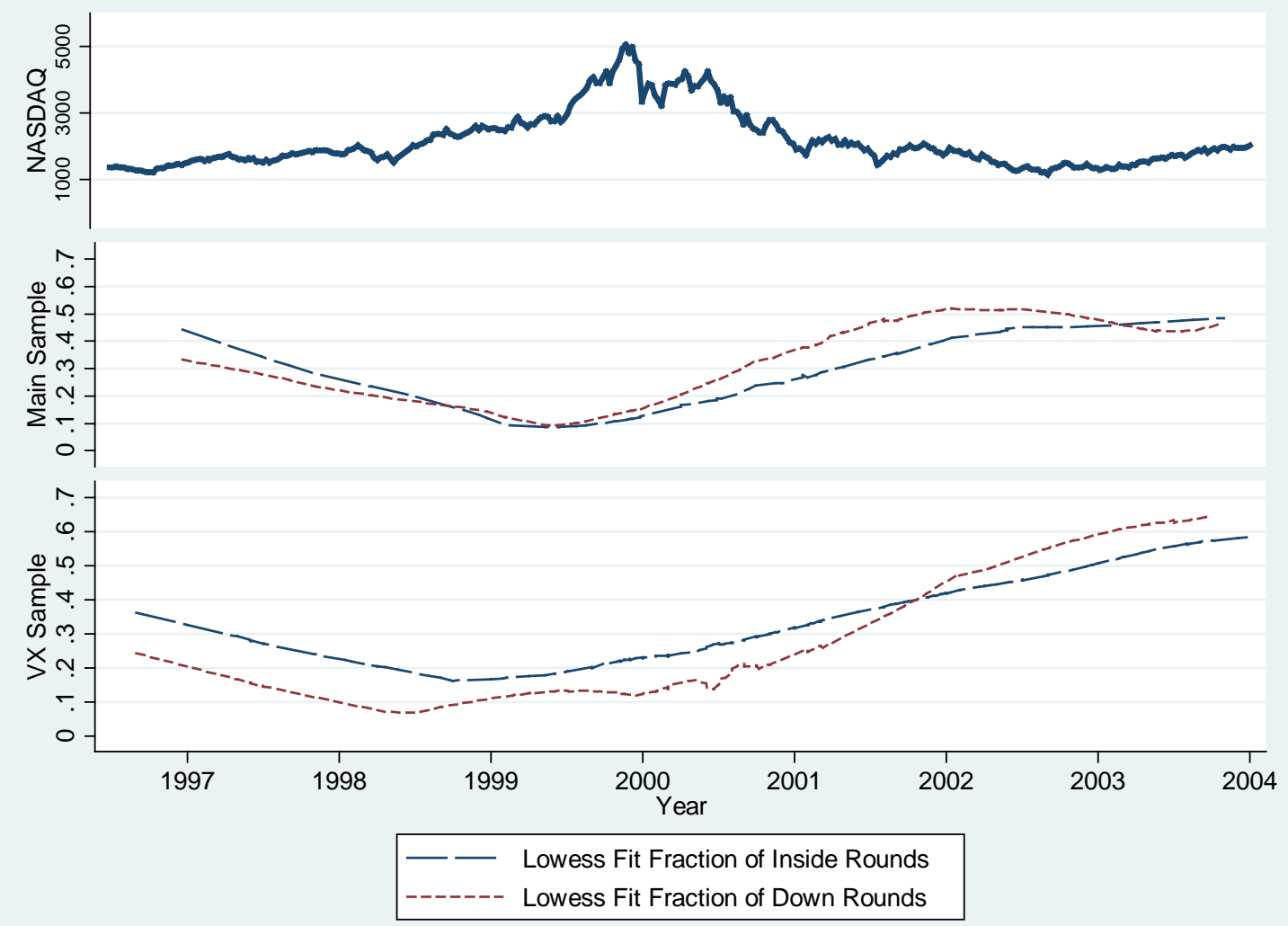

\section{Clustering of Inside Financing in Down and Even Rounds.}

As in the main sample, inside financing in the VX sample is clustered in down rounds and even rounds. In the main sample, approximately 92\% of inside rounds were down or flat (compared to 33\% of outside rounds). In the VX sample rounds for which sufficient data are available, $64 \%$ of inside rounds are down or flat (compared to $37 \%$ of outside rounds). However, a disproportionate number of inside rounds are missing valuation data, a pattern encountered by other researchers (Kaplan, Sensoy, \& Stromberg, 2002). Poorlyperforming firms may be less likely to report valuations to VX. 


\section{Inside Round Performance}

In the main sample, inside rounds are associated with lower returns. While VX does not provide information on round returns, it does indicate the exit status of the firm: IPO, private sale, defunct, or active (no exit yet). Since IPOs and M\&As are generally associated with higher rates of return for VC investors than active (i.e. walking dead) or defunct firms, we can use exit outcome as a rough proxy for VC performance and for the returns associated with a financing round. For many defunct and active firms, the VCs may record a complete loss on the investment.

VX sample firms receiving inside financing are less likely to make it to a successful exit - an IPO or an M\&A. Table A2 reports that IPO firms receive $21 \%$ of their follow-on financings as inside rounds. Acquired firms receive 34\% of their follow-on investments as inside rounds. This compares to 55\% for active firms and $44 \%$ for defunct firms. Furthermore, the VX sample contains a total of 76 inside rounds in defunct and active firms, compared to only 10 inside rounds in IPO firms. If anything, our main sample is likely to over-represent successful inside rounds and under-represent failing inside rounds. While we cannot measure IRR directly for the VX sample firms, the clustering of inside rounds in firms that have bad exit outcomes is consistent with the use of inside rounds for backstop financing, and inconsistent with the use of inside rounds for dilution.

\section{Bibliography}

Admati, A., Pfleiderer, P., 1994. Robust financial contracting and the role of venture capitalists. Journal of Finance 49, 371-402.

Atanasov, V., Ivanov, V., Litvak, K., 2008. The effect of litigation on venture capitalist reputation. Available at SSRN: http://ssrn.com/abstract=1120994.

Bartlett, J., Garlitz, K., 1995. Fiduciary duties in burnout/cramdown financings. Journal of Corporation Law 20, 595-626.

Bartlett, R., 2003. Understanding price-based antidilution protection: Five principles to apply when negotiating a down-round financing. Bus. Law. 59, 23-42.

Bebchuk, L., Cohen, A., 2003. Firms’ decisions where to incorporate. Journal of Law and Economics 46, 383-425. 
Bengtsson, O., Sensoy, B., 2009. Changing the nexus: The evolution and renegotiation of venture capital contracts. SSRN: http://ssrn.com/abstract=1475347

Bengtsson, O., Ravid, A., 2010. Geography and financial contracts. Available at SSRN: http://ssrn.com/abstract=1570614

Black, B., Gilson, R., 1998. Venture capital and the structure of capital markets: Banks versus stock markets. Journal of Financial Economics 47, 243-277.

Brander, J., Amit, R., Antweiler, W., 2002. Venture capital syndication: Improved venture selection vs. value-added hypothesis. Journal of Economics and Management Strategy 11, $422-452$.

Broughman, B., 2010. Investor opportunism and governance in venture capital, in D. Cumming, eds., Venture capital: Investment strategies, structures, and policies, Robert W. Kolb series in finance, 347-364.

Broughman, B., Fried, J., 2010. Renegotiation of cash flow rights in the sale of VC-backed firms. Journal of Financial Economics 95, 384-399.

Cochrane, J., 2005. The risk and return of venture capital. Journal of Financial Economics 75, 3-52.

Cumming, D., Walz, U., 2010. Private equity returns and disclosure around the world. Journal of International Business Studies 41, 727-754.

Cumming, D., Dai, N., 2011. Fund size, limited attention and valuation of venture capital backed firms. Journal of Empirical Finance 18, 2-15.

Da Rin, M. Hellmann, T., Puri, M., 2011. A survey of venture capital research. Available at http://ssrn.com/abstract=1942821.

Daines, R., 2002. The incorporation choices of IPO firms. New York University Law Review 77, 1559-1610.

Fluck, Z., Garrison, K., Myers, S. 2005. Venture capital contracting and syndication: an experiment in computational corporate finance. Unpublished working paper.

Fried, J., Ganor, M., 2006. Agency costs of venture capitalist control in startups. New York University Law Review 81, 967-1025.

Gompers, P., Lerner, J., 1999. The venture capital cycle. Cambridge MA: MIT Press.

Gompers, P., Lerner, J., 2000. Money chasing deals? the impact of fund inflows on private equity valuations. Journal of Financial Economics 55, 281 - 325.

Gompers, P., 1995. Optimal investment, monitoring, and the staging of venture capital. Journal of Finance 50, 1461-1489.

Hellmann, Thomas. 1998. The allocation of control rights in venture capital contracts. RAND Journal of Economics 29, 57-76.

Hellmann, T., Puri, M., 2000. The interaction between product market and financing strategy: the role of venture capital. Review of Financial Studies 13, 959-84.

Heughebaert, A., Manigart, S., 2010. Firm valuation in venture capital financing rounds: the role of investor bargaining power. Available at http://ssrn.com/abstract=1729773.

Hochberg, Y., Ljungqvist, A., Lu, Y., 2007. Whom you know matters: venture capital networks and investment performance. Journal of Finance 62, $251-301$. 
Hsu, D., 2004. What do entrepreneurs pay for venture capital affiliation? Journal of Finance 59, 1805-1844.

Ioannidou, V., Ongena, S., 2010. “Time for a change”: Loan conditions and bank behavior when firms switch banks. Journal of Finance 65, 1847-1877.

Kaplan, S., Strömberg, P., 2003. Financial contracting theory meets the real world: An empirical analysis of venture capital contracts. Review of Economic Studies 70, 281-315.

King, K. 1997. Warning rescue may raise risks. The National Law Journal, Nov. 24. 1997

Klausner, M., Litvak, K., 2001. What economists have taught us about venture capital contracting. in M. Whincop, eds., Bridging the entrepreneurial financing gap: Linking governance with regulatory policy, Ashgate.

Lerner, J., 1994. The syndication of venture capital investments. Fin. Management 23, 16 - 27.

Lerner, J., 1995. Venture capitalists and the oversight of private firms. J. Finance 50, 301-318.

Metrick, A. 2007. Venture capital and the finance of innovation, John Wiley and Sons, Inc.

Metrick, A., Yasuda, A., 2011. Venture capital and other private equity: a survey. European Financial Management 17, 619-654.

Padilla, J., 2001. What's wrong with a washout?: fiduciary duties of the venture capitalist investor in a washout financing. Houston Business and Tax Law Journal 1, 269-306.

Puri, M., Zarutskie, R., forthcoming. On the lifecycle dynamics of venture-capital and non-venturecapital-financed firms. Journal of Finance.

Rajan, R., 1992. Insiders and outsiders: The choice between relationship and arm’s length debt, J. Finance 47, 1367-1400.

Roll, R., 1986. The hubris hypothesis of corporate takeovers. Journal of Business 59, 197-216.

Sharpe, S., 1990. Asymmetric information, bank lending and implicit contracts: A stylized model of customer relationships, J. Finance 45, 1069-1087.

Sorenson, O., Stuart, T., 2001. Syndication networks and the spatial distribution of venture capital investments. American Journal of Sociology 106, 1546-1688.

Staiger, D., Stock, J,. 1997. Instrumental variables regression with weak instruments. Econometrica 65, 557-586.

Tian, X., 2008. The role of venture capital syndication in value creation for entrepreneurial firms. at ssrn.com $/$ sbatract $=054188$

von Thadden, E., 2004. Asymmetric information, bank lending, and implicit contracts: The winner's curse. Finance Research Letters 1, 11-23. 


\section{Table 1: Description of the Dataset}

This table provides descriptive statistics for a sample of 45 Silicon Valley VC-backed firms sold in 2003 or 2004. Panel A shows the industry distribution, based on sector classifications provided by www.linksv.com. Panel B reports summary statistics for the sample firms.

Panel A: Industry Distribution of Companies

\begin{tabular}{ccccc} 
Biotech & Telecom & $\begin{array}{c}\text { Sector } \\
\text { Software }\end{array}$ & Internet & Other IT \\
\hline 6 & 11 & 11 & 9 & 8
\end{tabular}

Panel B: Firm Overview

\begin{tabular}{lccccc} 
& Obs & Count & Mean & Med. & SD \\
\hline Years of Operation & 45 & & 5.13 & 5 & 1.65 \\
Year Founded & 45 & & 1998.38 & 1998 & 1.77 \\
Number of Financing Rounds & 45 & & 3.00 & 3 & 1.01 \\
Total Invested (millions \$) & 45 & & 43.99 & 31 & 37.65 \\
Sale Price (millions \$) & 45 & & 55.22 & 22 & 108.95 \\
Firm IRR & 45 & & 0.20 & -0.13 & 2.03 \\
Profitable & 45 & 16 & 0.36 & 0 & 0.48 \\
Number of Founders & 45 & & 2.31 & 2 & 1.24 \\
Serial Entrepreneur & 45 & 20 & 0.44 & 0 & 0.50 \\
Prior Experience with VC & 45 & 23 & 0.51 & 1 & 0.51 \\
California Incorporation & 45 & 14 & 0.31 & 0 & 0.47 \\
Delaware Incorporation & 45 & 31 & 0.69 & 1 & 0.47
\end{tabular}




\section{Table 2: Variable Definitions and Correlation Matrix}

This table defines the round-level variables for a sample of 45 Silicon Valley VC-backed firms sold in 2003 or 2004 . The following correlation matrix shows the mean and pairwise correlations among the variables in the sample. Data are only presented for 90 follow-on rounds of financing. First round financing is excluded since it does not apply to many of the variables below.

Round IRR equals the internal rate of return for each round of VC financing; Inside equals 1 if a new round of financing is provided entirely by a firm's existing investors and 0 otherwise; VC Control equals 1 if the VCs control the board immediately preceding a round of financing and 0 otherwise; California equals 1 if the firm is incorporated in California and 0 otherwise; VC Ownership \% equals the fraction of a firm's cash flow rights on a fully converted basis collectively held by its existing VCs immediately prior to a follow-on round of financing; $\triangle N A S D A Q S a l e$ (\%) equals the percentage change in the closing price of the NASDAQ national market from the date of financing to the date of sale; $\triangle N A S D A Q$ equals the percentage change in the closing price of the NASDAQ national market from the date of the previous round of financing to the new follow-on round; VC Reputation equals one if the VC firm leading the round of financing was formed prior to the median year of formation for the VCs in our sample (1990), and zero otherwise; Duration Financing to Sale equals the number of years between the current round of financing and the sale of the firm; Investment equals the amount invested (in millions) in a round of financing; Number of Directors equals the number of directors on the board immediately prior to a new round of financing; Up equals 1 if a round of financing has a higher pre-money valuation than the post-money valuation of the previous round and 0 otherwise; Down equals 1 if a round of financing has a lower pre-money valuation than the post-money valuation of the previous round and 0 otherwise; Even equals 1 if a round of financing has the same pre-money valuation as the post-money valuation of the previous round and 0 otherwise.

\begin{tabular}{|c|c|c|c|c|c|c|c|c|c|c|c|c|c|c|c|c|}
\hline & & Mean & 1 & 2 & 3 & 4 & 5 & 6 & 7 & 8 & 9 & 10 & 11 & 12 & 13 & 14 \\
\hline 1 & Round IRR & -.04 & - & & & & & & & & & & & & & \\
\hline 2 & Inside & .29 & -.01 & - & & & & & & & & & & & & \\
\hline 3 & VC Control & .23 & -.01 & .23 & - & & & & & & & & & & & \\
\hline 4 & California & .34 & .07 & -.10 & -.18 & - & & & & & & & & & & \\
\hline 5 & VC Ownership \% & .59 & -.03 & .27 & .28 & -.03 & - & & & & & & & & & \\
\hline 6 & $\triangle$ NASDAQ Sale (\%) & -.09 & .36 & .25 & .09 & -.26 & -.04 & - & & & & & & & & \\
\hline 7 & $\triangle$ NASDAQ & -.35 & -.35 & -.20 & -.02 & .12 & .09 & -.52 & - & & & & & & & \\
\hline 8 & VC Reputation & .44 & .09 & .22 & -.07 & .10 & .12 & .11 & -.04 & - & & & & & & \\
\hline 9 & Duration Fin to Sale & 2.63 & -.44 & -.26 & -.27 & .06 & -.19 & -.37 & .54 & -.05 & - & & & & & \\
\hline 10 & Investment & 16.46 & -.11 & -.20 & -.06 & .09 & .22 & -.28 & .21 & -.08 & .03 & - & & & & \\
\hline 11 & Number of Directors & 5.16 & .17 & .12 & .20 & .26 & .56 & .09 & -.10 & .09 & -.28 & .08 & - & & & \\
\hline 12 & Up & .50 & -.09 & -.54 & -.13 & .07 & -.17 & -.44 & .37 & -.09 & .35 & .27 & -.15 & - & & \\
\hline 13 & Down & .34 & .03 & .31 & .15 & -.13 & .25 & .30 & -.29 & .06 & -.40 & -.16 & .13 & -.72 & - & \\
\hline 14 & Even & .16 & .07 & .34 & -.02 & .08 & -.09 & .21 & -.13 & .05 & .04 & -.16 & .04 & -.43 & -.31 & - \\
\hline
\end{tabular}




\section{Figure 1. The Relationship Between Inside Rounds and Valuation Changes}

Figure 1 illustrates the relationship between the use of inside rounds and valuation changes since the last round of financing. The data are from a sample of 90 follow-on rounds of financing from 45 VC-backed firms sold in 2003 or 2004. The horizontal axis indicates the amount of valuation change since the last round. "Even” means no change in the valuation. “-25" means that the valuation change was negative but not less than -25\%; "25” means that the valuation change was positive but not greater than 25\%. The table below Figure 1 reports the percent of outside and inside rounds that are Up, Even, and Down. The table includes a difference of means t-test comparing the distribution of inside and outside rounds.

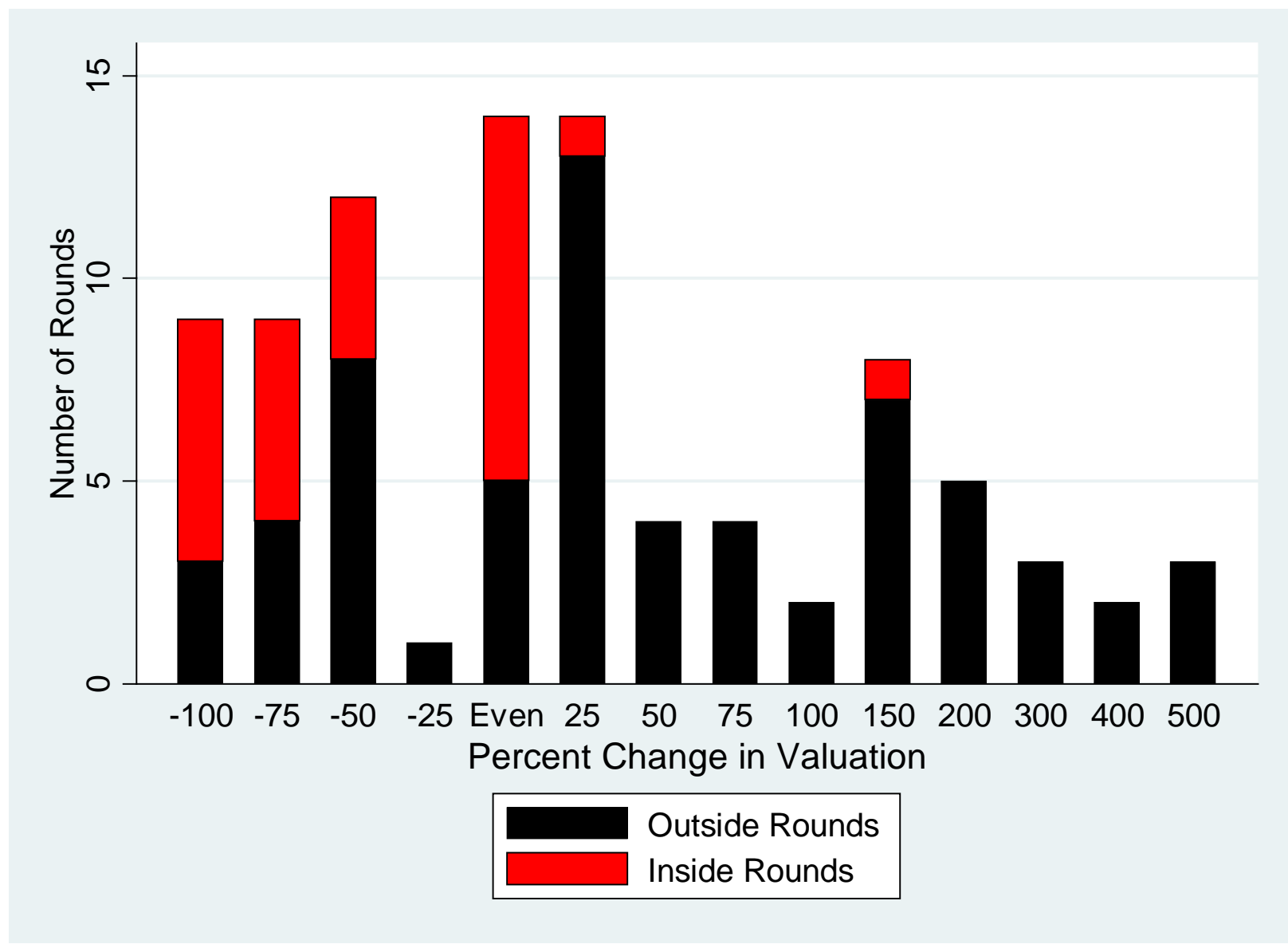

\begin{tabular}{|l|c|c|c|c|}
\hline Follow-on Rounds & (n= $)$ & Up & Even & Down \\
\hline All Follow-on Rounds & 90 & $50 \%$ & $16 \%$ & $34 \%$ \\
\hline Outside rounds & 64 & $67 \%$ & $8 \%$ & $25 \%$ \\
\hline Inside rounds & 26 & $8 \%$ & $35 \%$ & $58 \%$ \\
\hline t-test for Equal Means & & $-6.01 * * *$ & $3.34 * * *$ & $3.08 * * *$ \\
\hline
\end{tabular}

$*=10 \%$ significance; $* *=5 \%$ significance $; * *=1 \%$ significance 


\section{Figure 2: Inside Financing by Year}

Figure 2 illustrates the use of inside rounds and down rounds based on the time of financing. The data are from a sample of 45 VC-backed firms sold in 2003 or 2004, covering 90 follow-on rounds of investment. The top portion of the diagram graphs the NASDAQ weekly closing price from the beginning of 1997 to the end of 2003. The bottom portion of the diagram uses a Lowess curve to plot the likelihood of inside financing and down-round financing over the same time period. Below the graph is a table reporting the fraction of the follow-on rounds that were inside and down-rounds for each year.

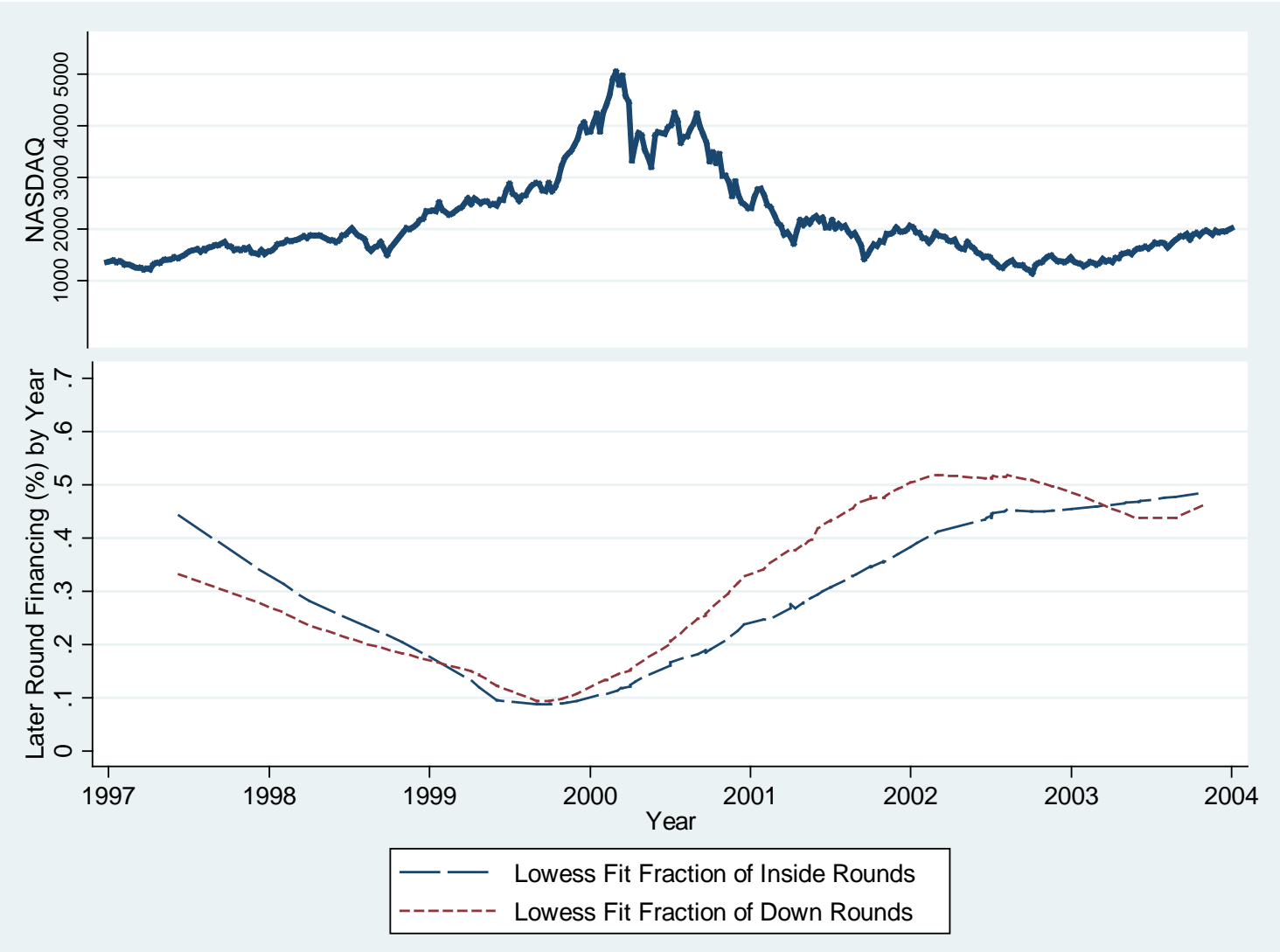

Observation

\begin{tabular}{cccccc}
\multicolumn{7}{c}{ Year of Financing } \\
$\leq \mathbf{1 9 9 8}$ & $\mathbf{1 9 9 9}$ & $\mathbf{2 0 0 0}$ & $\mathbf{2 0 0 1}$ & $\mathbf{2 0 0 2}$ & $\mathbf{2 0 0 3}$ \\
\hline 6 & 12 & 18 & 24 & 19 & 11 \\
0.33 & 0.00 & 0.17 & 0.29 & 0.47 & 0.45 \\
0.17 & 0.00 & 0.06 & 0.42 & 0.63 & 0.55
\end{tabular}




\section{Figure 3: Firm-Level IRR Sorted by Percentage of Inside Financing}

Figure 3 illustrates Firm IRR for each firm in a sample of 45 VC-backed firms sold in 2003 or 2004. Data are sorted based on the fraction of financing dollars each firm receives through inside rounds. To preserve confidentiality (and for ease of presentation) Firm IRR is capped at 1 . The fitted line illustrates a negative correlation between inside financing and Firm IRR. The table immediately below the diagram shows the number of profit firms (Firm IRR $>0$ ) and the mean Firm IRR (on unweighted and investment-dollar weighted bases) sorted by the number of inside rounds received.

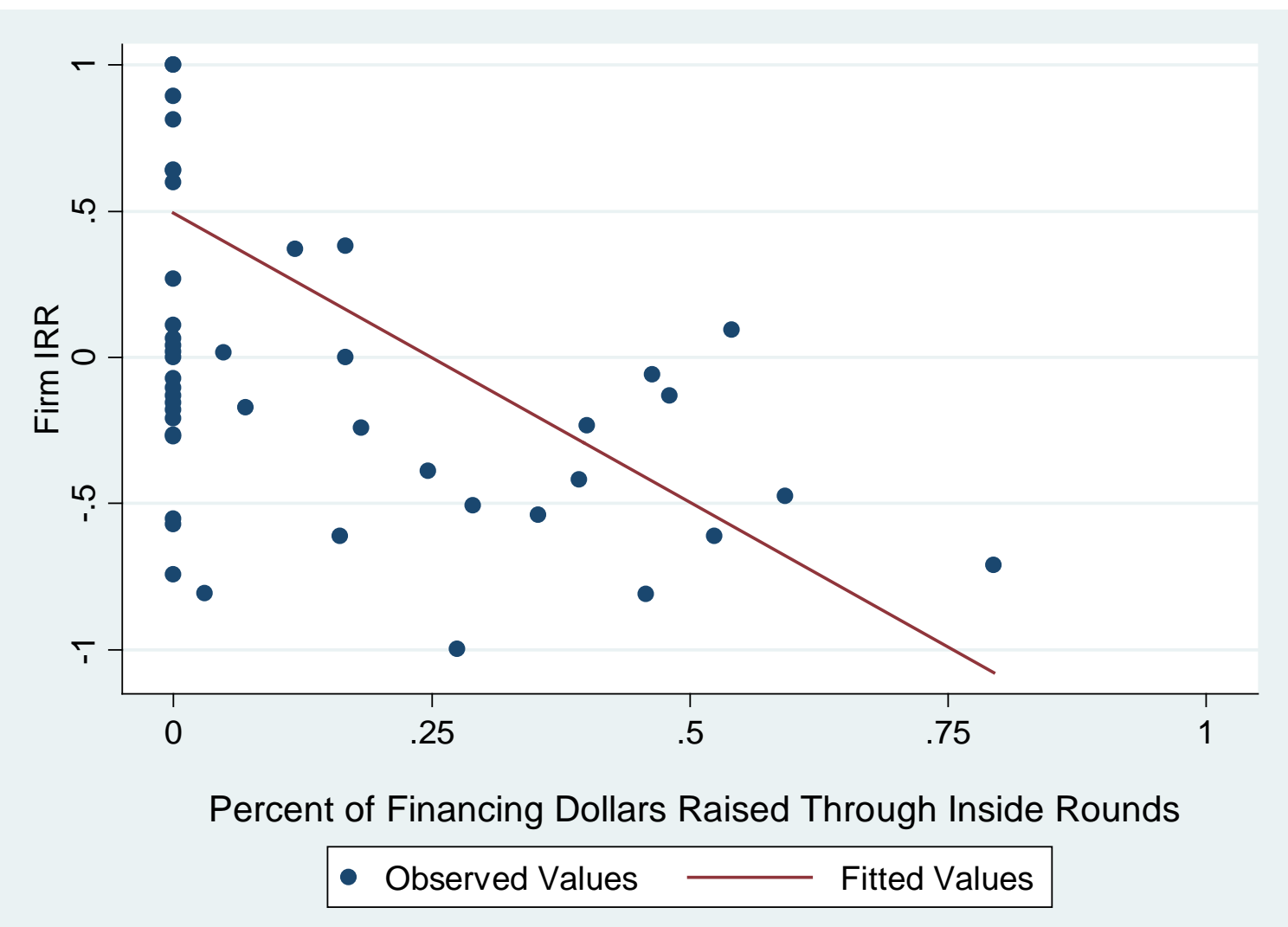

\begin{tabular}{lcccc}
$\begin{array}{l}\text { Number of Inside } \\
\text { Rounds }\end{array}$ & Obs. & $\begin{array}{c}\text { Number (\%) of Profit } \\
\text { Firms }\end{array}$ & $\begin{array}{c}\text { Mean IRR } \\
\text { (unweighted) }\end{array}$ & $\begin{array}{c}\text { Mean IRR } \\
\text { (\$ weighted) }\end{array}$ \\
\hline $\mathbf{0}$ & 24 & $12(50 \%)$ & .652 & .097 \\
$\mathbf{1}$ & 16 & $4(25 \%)$ & -.314 & -.255 \\
$\mathbf{2}$ & 5 & $0(0 \%)$ & -.363 & -.278 \\
\hline All Firms & $\mathbf{4 5}$ & $\mathbf{1 6 ( 3 6 \% )}$ & $\mathbf{. 1 9 5}$ & -.126 \\
At Least One Rd. & $\mathbf{2 1}$ & $\mathbf{4 ( 1 9 \% )}$ & -.326 & -.259
\end{tabular}




\section{Table 3: Univariate Difference of Means Test}

This table reports various differences of means from a sample of 45 VC-backed firms sold in 2003 or 2004. Data are separately reported for firms that received at least one inside round of financing and firms that had only outside rounds. The final column reports t-stats for a difference of means test. Panel A reports differences between Profit firms (Firm IRR $>0$ ) and Loss firms (Firm IRR $<0$ ), with respect to the use of inside financing.

\section{Panel A - Firm Profitability}

\begin{tabular}{lccc} 
& Inside $(\mathrm{n}=21)$ & Outside $(\mathrm{n}=24)$ & \\
\hline Profitable & 0.19 & 0.50 & $-2.23^{* *}$ \\
IRR & -0.33 & 0.65 & $-1.75^{*}$ \\
IRR (\$ weighted) & -0.26 & 0.10 & -1.67 \\
& & & \\
\hline Inside Firm & Profit $(\mathrm{n}=16)$ & Loss $(\mathrm{n}=29)$ & $-2.32^{* *}$ \\
Dollar Inside \% & 0.25 & 0.59 & $-2.70^{* * *}$ \\
Number of Inside Rounds & 0.05 & 0.20 & $-2.87^{* * *}$ \\
\hline
\end{tabular}

$*, * *$, or $* * *$ indicate statistical significance at the $10 \%, 5 \%$, or $1 \%$ level respectively 


\section{Figure 4: Last Round Valuation over Sale Price}

Figure 4 illustrates the ratio of the (Last Round Valuation)/(Sale Price) ('LRV/SP') from a sample of 45 VC-backed firms sold in 2003 or 2004 . Data are sorted based on whether the last round was an inside round or an outside round. The diagram below illustrates the distribution of LRV/SP for inside rounds and outside rounds using a standard box plot (with outlier values excluded).

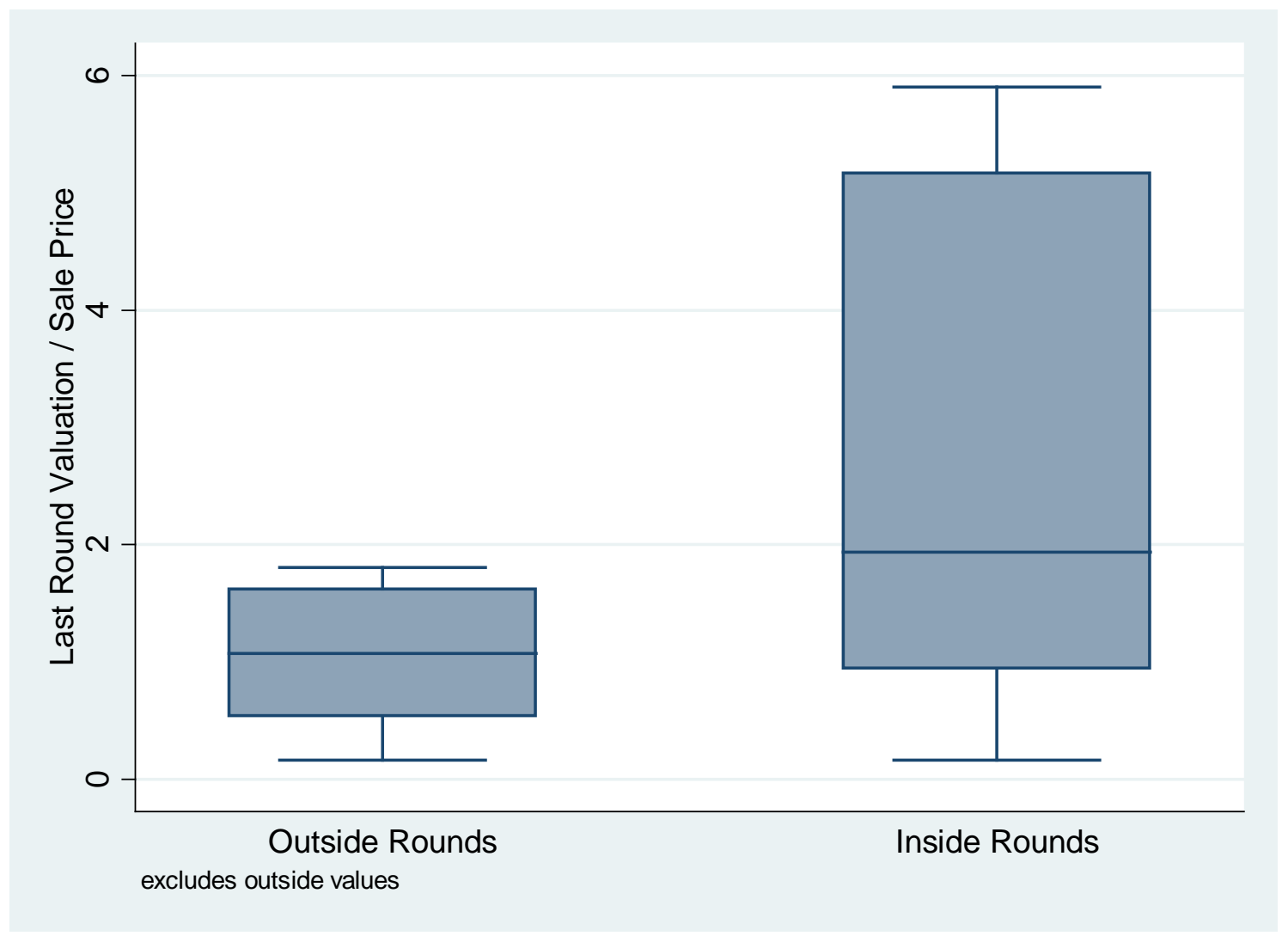




\section{Table 4: Regression Analysis of Valuation: Inside versus Outside Financing}

This table reports ordinary least squares (OLS), weighted least squares (WLS), and robust regression (RREG) estimates on a sample of 45 VC-backed firms sold in 2003 or 2004. The dependent variable is Log Last Round over Sale, which measures the log of the ratio of the last round valuation (nominal) ${ }^{17}$ to the sale price. The unit of analysis is the last round of financing, and consequently there is only one observation for each firm. The treatment variable records whether the last round of financing was an inside round [Inside]. All remaining explanatory variables are defined in Table 2. The WLS estimates reported in model (4-4) are weighted based the amount invested in the round. Robust (White, 1980) standard errors are reported in parentheses below each coefficient estimate. We use a two-sided test for statistical significance.

\begin{tabular}{|c|c|c|c|c|c|c|}
\hline & $(4-1)$ & $\begin{array}{l}\text { OLS } \\
(4-2)\end{array}$ & $(4-3)$ & $\begin{array}{l}\text { WLS } \\
(4-4)\end{array}$ & $\begin{array}{c}\text { RREG } \\
(4-5)\end{array}$ & $\begin{array}{l}\text { OLS } \\
(4-6)\end{array}$ \\
\hline $\begin{array}{l}\text { Treatment Variable } \\
\text { Inside }\end{array}$ & $\begin{array}{l}.912^{* *} \\
(.447)\end{array}$ & $\begin{array}{l}.942 * * \\
(.461)\end{array}$ & $\begin{array}{l}.800^{*} \\
(.469)\end{array}$ & $\begin{array}{l}1.127 * \\
(.577)\end{array}$ & $\begin{array}{c}1.078^{* * * *} \\
(.352)\end{array}$ & $\begin{array}{l}.373^{*} \\
(.191)\end{array}$ \\
\hline $\begin{array}{l}\text { Control Variables } \\
\text { VC Control }\end{array}$ & & $\begin{array}{c}1.563^{* * * *} \\
(.580)\end{array}$ & $\begin{array}{c}1.760 * * * \\
(.591)\end{array}$ & $\begin{array}{c}1.441^{* *} \\
(.674)\end{array}$ & $\begin{array}{c}1.005^{* *} \\
(.392)\end{array}$ & $\begin{array}{c}.723 \\
(.494)\end{array}$ \\
\hline California & & $\begin{array}{l}.980 * * \\
(.419)\end{array}$ & $\begin{array}{c}.983 * * * \\
(.349)\end{array}$ & $\begin{array}{c}1.089 * * \\
(.408)\end{array}$ & $\begin{array}{l}.669 * \\
(.393)\end{array}$ & $\begin{array}{c}1.221^{* *} \\
(.399)\end{array}$ \\
\hline$\Delta$ NASDAQ Sale (\%) & & $\begin{array}{l}-.213 \\
(.693)\end{array}$ & $\begin{array}{l}-.352 \\
(.626)\end{array}$ & $\begin{array}{l}-.795 \\
(.731)\end{array}$ & $\begin{array}{l}.443 \\
(.545)\end{array}$ & $\begin{array}{c}1.711 \\
(1.051)\end{array}$ \\
\hline VC Reputation & & $\begin{array}{l}-.394 \\
(.455)\end{array}$ & $\begin{array}{l}-.052 \\
(.404)\end{array}$ & $\begin{array}{c}-1.050^{*} \\
(.595)\end{array}$ & $\begin{array}{l}-.433 \\
(.356)\end{array}$ & $\begin{array}{l}.148 \\
(.355)\end{array}$ \\
\hline Duration Fin to Sale & & $\begin{array}{l}.540 * * \\
(.216)\end{array}$ & $\begin{array}{l}.541^{* *} \\
(.207)\end{array}$ & $\begin{array}{l}.451^{*} \\
(.253)\end{array}$ & $\begin{array}{l}.501^{*} \\
(.260)\end{array}$ & $\begin{array}{l}.204 \\
(.384)\end{array}$ \\
\hline Investment & & $\begin{array}{l}.009 \\
(.024)\end{array}$ & $\begin{array}{l}.017 \\
(.018)\end{array}$ & $\begin{array}{l}.013 \\
(.020)\end{array}$ & $\begin{array}{l}.008 \\
(.017)\end{array}$ & $\begin{array}{c}-.037 * * * \\
(.011)\end{array}$ \\
\hline Industry Dummies & & & YES & & & \\
\hline Constant & $\begin{array}{l}.237 \\
(.286)\end{array}$ & $\begin{array}{l}-1.337 \\
(.524)\end{array}$ & $\begin{array}{l}-1.182 \\
(.549)\end{array}$ & $\begin{array}{l}-.960 \\
(.719)\end{array}$ & $\begin{array}{l}-1.323 \\
(.571)\end{array}$ & $\begin{array}{l}-1.309 \\
(.813)\end{array}$ \\
\hline $\begin{array}{l}\mathrm{R}^{2} \\
\text { F-stat } \\
\text { No. of Observations }\end{array}$ & $\begin{array}{c}.09 \\
- \\
45\end{array}$ & $\begin{array}{c}.43 \\
- \\
45\end{array}$ & $\begin{array}{c}.56 \\
- \\
45\end{array}$ & $\begin{array}{c}.51 \\
- \\
45\end{array}$ & $\begin{array}{c}- \\
3.26 \\
45\end{array}$ & $\begin{array}{l}.75 \\
- \\
16\end{array}$ \\
\hline
\end{tabular}

$*=10 \%$ significance $* *=5 \%$ significance $* * *=1 \%$ significance [2-sided test]

\footnotetext{
${ }^{17}$ The results reported in this table are unaffected by the method of valuation. We find similar results if we use implied valuations (Metrick, 2007) instead.
} 


\section{Figure 5: Round IRR over Time of Financing}

Figure 5 shows the IRR for each follow-on round of financing in a sample of 45 VC-backed firms sold in 2003 or 2004, covering 90 discrete follow-on rounds. Outside rounds are indicated with blue dots while inside rounds are indicated with red dots. The graph also shows a Lowess curve plotting the IRR over time for outside rounds (green curve) and for inside rounds (orange curve).

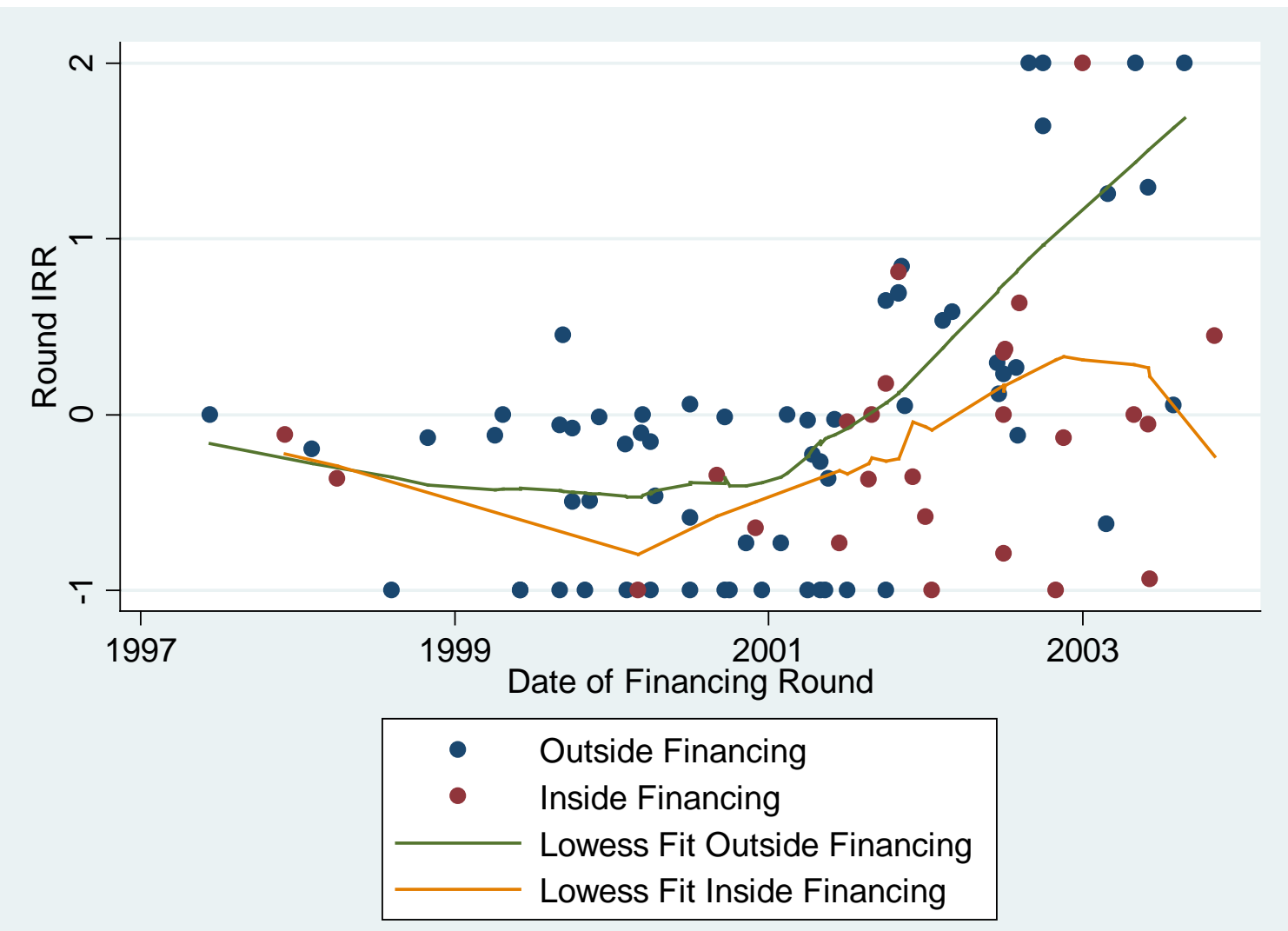

